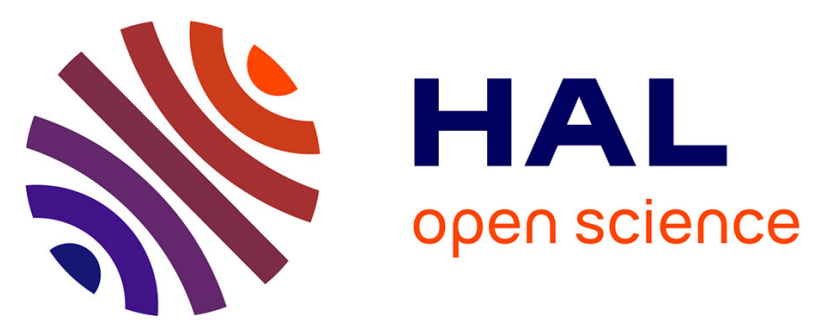

\title{
Degradable Copolymer Nanoparticles from Radical Ring-Opening Copolymerization between Cyclic Ketene Acetals and Vinyl Ethers
}

Johanna Tran, Théo Pesenti, Jonathan Cressonnier, Catherine Lefay, Didier

Gigmes, Yohann Guillaneuf, Julien Nicolas

\section{To cite this version:}

Johanna Tran, Théo Pesenti, Jonathan Cressonnier, Catherine Lefay, Didier Gigmes, et al.. Degradable Copolymer Nanoparticles from Radical Ring-Opening Copolymerization between Cyclic Ketene Acetals and Vinyl Ethers. Biomacromolecules, 2018, 20 (1), pp.305-317. 10.1021/acs.biomac.8b01500 . hal-02323730

\section{HAL Id: hal-02323730 \\ https://hal.science/hal-02323730}

Submitted on 21 Oct 2019

HAL is a multi-disciplinary open access archive for the deposit and dissemination of scientific research documents, whether they are published or not. The documents may come from teaching and research institutions in France or abroad, or from public or private research centers.
L'archive ouverte pluridisciplinaire HAL, est destinée au dépôt et à la diffusion de documents scientifiques de niveau recherche, publiés ou non, émanant des établissements d'enseignement et de recherche français ou étrangers, des laboratoires publics ou privés. 


\section{Degradable Copolymer Nanoparticles from Radical}

\section{Ring-Opening Copolymerization between Cyclic}

\section{Ketene Acetals and Vinyl Ethers}

Johanna Tran, ${ }^{1}$ Théo Pesenti, ${ }^{1}$ Jonathan Cressonnier, ${ }^{1}$ Catherine Lefay, ${ }^{2}$ Didier Gigmes, ${ }^{2}$ Yohann Guillaneuf, ${ }^{2}$ Julien Nicolas, ${ }^{1, *}$

${ }^{1}$ Institut Galien Paris-Sud, UMR CNRS 8612, Univ Paris-Sud, Faculté de Pharmacie, 5 rue Jean-Baptiste Clément, F-92296 Châtenay-Malabry cedex, France.

${ }^{2}$ Aix-Marseille Université, CNRS. Institut de Chimie Radicalaire, UMR 7273, Marseille, France

*To whom correspondence should be addressed.

Email: julien.nicolas@u-psud.fr

Tel.: +33146835853 


\begin{abstract}
2-methylene-1,3-dioxepane (MDO) and different vinyl ether (VE) monomers were successfully copolymerized by free-radical radical ring-opening copolymerization (rROP) to yield P(MDO-co-VE) copolymers with $M_{\mathrm{n}}=7000-13000 \mathrm{~g} \cdot \mathrm{mol}^{-1}$ and high molar fractions of MDO $\left(F_{\mathrm{MDO}}=0.7-0.9\right)$. By using VE derivatives of different aqueous solubilities or by grafting PEG chains onto the copolymers by "click" chemistry via azide-containing VE units, hydrophobic, amphiphilic or even water-soluble copolymers were obtained. The different copolymers were then formulated into nanoparticles by nanoprecipitation using Pluronics for hydrophobic copolymers, without surfactant for amphiphilic copolymers, or blended with PMDO for water-soluble copolymers. Most of the copolymers led to nanoparticles with average diameters in the $130-250 \mathrm{~nm}$ with narrow particle size distributions and satisfying colloidal stability for a period of at least 1-2 weeks and up to 6 months. The copolymers were successfully degraded under accelerated, hydrolytic or enzymatic conditions. Hydrophobic copolymers led to degradation kinetics in PBS similar to that of PCL and complete degradation (-95\% in $M_{\mathrm{n}}$ decrease) was observed in the presence of enzymes (lipases). Preliminary cytotoxicity assays were performed on endothelial cells (HUVEC) and macrophages (J774.A1) and revealed high cell viabilities at $0.1 \mathrm{mg} \cdot \mathrm{mL}^{-1}$.
\end{abstract}




\section{Introduction}

Developing materials for biomedical applications is the subject of extensive research. In particular, (bio)degradable polymers have aroused keen attention because not only they can be used in (nano)medicine but also in a wide range of other applications such as microelectronics and environmental protection. ${ }^{1-3}$ For drug delivery and tissue engineering, polymers should follow some criteria. They should be: (i) biocompatible, to ensure compatibility with the biological medium; (ii) well-defined, for batch-to-batch reproducibility purposes; (iii) biodegradable, at least for some applications where their accumulation/resistance may be detrimental and (iv) possibly functionalizable with molecules of interest to confer advanced properties.

The most studied biodegradable polymers are certainly aliphatic polyesters, which are synthesized by ring-opening polymerization (ROP) of cyclic monomers (e.g., lactide, glycolide, caprolactone, etc.). Notably, these (co)polymers are approved by the Food and Drug Administration (FDA) for use in humans. ${ }^{4}$ Although they present important advantages and they are still considered as the gold standards, their synthesis is not always straightforward and their functionalization is relatively limited and/or rather tedious. ${ }^{5-8}$ On the other hand, vinyl polymers present numerous advantages such as their facile synthesis, the wide range of compositions and architectures that can be easily obtained, especially by reversible deactivation radical polymerization (RDRP), and their easiness of functionalization. However, their carbon-carbon backbone resists degradation which may be detrimental if biomedical applications are envisioned. Thus, combining the best of two worlds by developing synthetic strategies to generate (bio)degradable vinyl materials would be advantageous and would be a real step forward towards the use of vinyl materials in biomedical applications. Among the different strategies to confer degradability to vinyl polymers, ${ }^{9}$ radical ring-opening polymerization (rROP) is perhaps the most potent one. ${ }^{10}$ It 
relies on the polymerization of cyclic monomers, mainly cyclic ketene acetals (CKAs) $)^{10,11}$ and sulfide cyclic methacrylates, ${ }^{12}$ that lead to insertion of labile groups (e.g., ester, disulfide, thioester) in the polymer backbone through a radical ring-opening mechanism. CKAs are probably the most studied monomers for rROP. They were the subject of extensive research in the $1980 \mathrm{~s}^{13-17}$ and recently regained interest to obtain degradable vinyl copolymers for different bio-related applications. ${ }^{18-29}$ Such monomers can indeed be copolymerized, by freeradical polymerization or RDRP, with certain traditional vinyl monomers (e.g., vinyl acetate, methacrylic esters) to yield degradable or segmentable copolymers; depending on the amount of labile groups inserted. One of the main limitations of rROP from CKAs, however, is their unfavorable reactivity ratios when copolymerized with vinyl monomers. ${ }^{10}$ Thus, a large excess of CKA is required in the initial comonomer feed to ensure a sufficient amount in the resulting copolymer. Yet, the final molar fraction of CKA is often limited and gradient-type copolymers are usually obtained.

In this context, we recently reported on a quasi-ideal radical ring-opening copolymerization system between CKA and vinyl ether (VE) derivatives. ${ }^{30}$ We showed that free-radical copolymerization of 2-methylene-1,3-dioxepane (MDO) and butyl vinyl ether (BVE) gave much more favourable reactivity ratios $\left(r_{\mathrm{MDO}}=0.73\right.$ and $\left.r_{\mathrm{BVE}}=1.61\right)$ and resulted in nearly random copolymers with tuneable MDO contents, up to high values $(\sim 90$ mol.\%). Importantly, given many functional VE derivatives are commercially available, this approach was readily applied to the synthesis of: (i) fluorescent and amphiphilic copolymers obtained by post-functionalization strategies (e.g., nucleophilic substitution, "click" chemistry); (ii) bioelastomers with suitable properties for tissue engineering applications by using a difunctional VE and (iii) antibacterial films. 

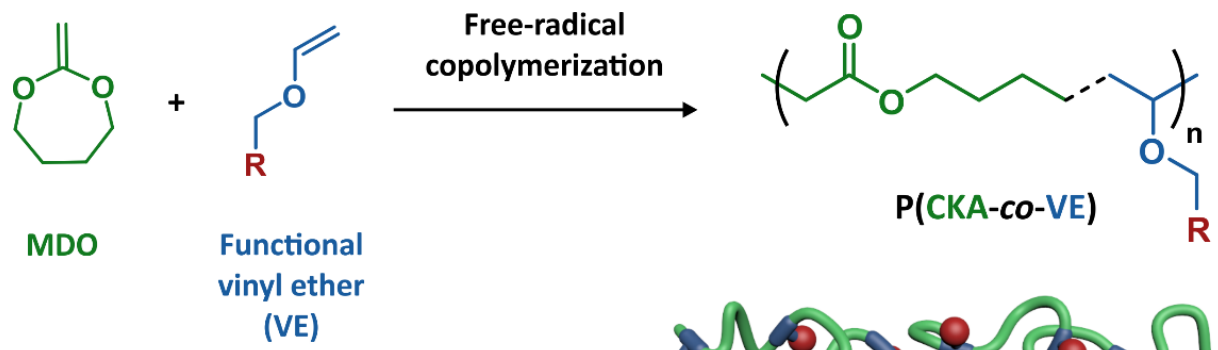

$\mathrm{R}=\mathrm{Me}, \mathrm{EtCl}, \mathrm{Bu}, \mathrm{EG}_{4} \mathrm{Me}$

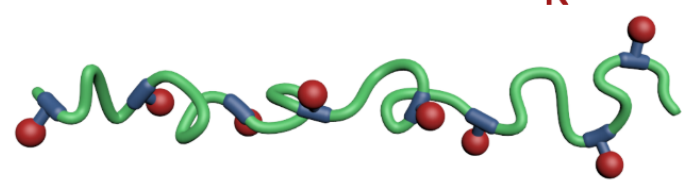

Figure 1. Synthesis of degradable vinyl copolymers by nearly ideal free-radical ring-opening copolymerization between 2-methylene-1,3-dioxepane (MDO) and vinyl ether (VE) derivatives.

Herein, given the very few examples of degradable vinyl materials for biomedical purposes described in the literature, we explored the potential of this new copolymerization system between MDO and VE derivatives (Figure 1) for the preparation degradable copolymer nanoparticles for potential drug delivery applications. A series of hydrophobic, amphiphilic or water-soluble $\mathrm{P}(\mathrm{MDO}-\mathrm{co}$-VE) copolymers obtained by different synthetic routes were prepared by rROP and formulated into nanoparticles whose colloidal properties and preliminary cytotoxicity were investigated. Degradation of the different copolymers were also monitored under different conditions to assess the degradability of those materials. Not only this study reports the preparation of a new class of degradable polymer nanoparticles with interesting potential in the biomedical field, but it also represents the first example of hydrolytically and enzymatically degradable, functional vinyl copolymers mainly composed of CKA units (PCL-like). 


\section{Experimental part}

\section{Materials}

All reagents and solvents were used as received except $\mathrm{CuBr}$ which was purified by stirring in acetic acid, washed with ethanol then diethyl ether. Bromoacetaldehyde dimethyl acetal (97\%), 1,4-butanediol (99\%), para-toluenesulfonic acid monohydrate ( $\geq 98.5 \%)$, Aliquat ${ }^{\circledR}$ 336, potassium tert-butoxide (> $98 \%$ ), 2-chloroethyl vinyl ether (CEVE) (99 \%), tetra(ethylene glycol) methyl vinyl ether (TEGVE), $\mathrm{NaN}_{3}(99 \%)$, 4-pentynoic acid (95\%), 4(dimethylamino)pyridine (DMAP) ( $\geq 99 \%), N, N^{\prime}$-dicyclohexylcarbodiimide (DCC) (99\%), $N, N, N$ ',N', $N$ ''-pentamethyldiethylenetriamine (PMDETA) (99 \%), CuBr (98\%), 1,1'carbonyldiimidazole (CDI) (reagent grade), poly(ethylene glycol) methyl ether (MePEG) $\left(M_{\mathrm{n}}=2000 \mathrm{~g} \cdot \mathrm{mol}^{-1}\right.$ and $\left.M_{\mathrm{n}}=750 \mathrm{~g} \cdot \mathrm{mol}^{-1}\right)$, lipases immobilized from Candida antarctica $\left(>2 \mathrm{U}_{\mathrm{mg}}^{-1}\right.$ ), phosphate buffer saline (PBS) $1 \mathrm{X}, \mathrm{pH}=7.4$ and anhydrous solvents were purchased from Sigma Aldrich (Merck). 2-methylene-1,3-dioxepane (MDO) monomer was prepared by adapting a previously published method, using the cyclic bromoacetal as intermediate. $^{31}$ Alkyne-MePEG 750 was prepared according to a previous report. ${ }^{30}$ Diethylazobisisobutyrate (DEAB) was kindly supplied by Arkema. Aminopropylvinylether was kindly supplied by BASF. Deuterated chloroform was obtained from Eurisotop. All other solvents were purchased from Carlo-Erba at the highest grade.

\section{Analytical Methods}

Nuclear Magnetic Resonance Spectroscopy (NMR). NMR spectroscopy was performed in $5 \mathrm{~mm}$ diameter tubes in $\mathrm{CDCl}_{3}$ at $25{ }^{\circ} \mathrm{C}$. ${ }^{1} \mathrm{H}$ spectroscopy was performed on a Bruker Avance spectrometer at $300 \mathrm{MHz}$. The chemical shifts are reported in ppm ( $\delta$ units), and internal solvent signal $(\delta=7.26 \mathrm{ppm})$ was used as reference. The abbreviations used to designate the multiplicities are: $\mathrm{s}=$ singlet, $\mathrm{d}=$ doublet, $\mathrm{t}=$ triplet, $\mathrm{m}=$ multiplet. 
Size Exclusion Chromatography (SEC). SEC of copolymers was performed on a Tosoh EcoSEC HLC-8320 GPC with two columns from Agilent (PL-gel MIXED-D $300 \times 7.5 \mathrm{~mm}$, beads diameter $5 \mu \mathrm{m}$; linear part 400 to $4 \times 10^{5} \mathrm{~g} \cdot \mathrm{mol}^{-1}$ ). Analyses were performed at $35^{\circ} \mathrm{C}$ in chloroform (HPLC grade) at a flow-rate of $1 \mathrm{~mL} \cdot \mathrm{min}^{-1}$. Toluene was used as flow-rate marker. Samples were filtered with a $0.2 \mu \mathrm{m}$ PTFE filter before analysis. The calibration curve was based on poly(methyl methacrylate) (PMMA) (range $1850-1916000$ g.mol ${ }^{-1}$ ) or poly(ethylene glycol) (PEG) (range 194-16 100 g.mol ${ }^{-1}$ ) standards from Agilent. The EcoSEC Analysis software enabled the determination of the number-average molar mass $M_{\mathrm{n}}$, the weight-average molar mass $M_{\mathrm{w}}$ and the dispersity $\left(\bigoplus=M_{\mathrm{w}} / M_{\mathrm{n}}\right)$.

SEC of degraded copolymers was performed at $30{ }^{\circ} \mathrm{C}$ on a system equipped with two columns from Agilent (PL-gel MIXED-D $300 \times 7.5 \mathrm{~mm}$, beads diameter $5 \mu \mathrm{m}$; linear part 400 to $4 \times 10^{5}$ g.mol $^{-1}$ ) and a differential refractive index detector (Spectrasystem RI-150 from Thermo Electron Corp.) using $\mathrm{CHCl}_{3}+0.1$ vol.\% TFA as eluent, a Waters 515 HPLC Pump at a flow rate of $1 \mathrm{~mL} \cdot \mathrm{min}^{-1}$, and toluene was used as flow rate marker. Samples were filtered with a $0.2 \mu \mathrm{m}$ PTFE filter before analysis. The calibration curve was based on poly(methyl methacrylate) (PMMA) (range 1 850-1 916000 g.mol ${ }^{-1}$ ) standards from Agilent, allowing $M_{\mathrm{n}}, M_{\mathrm{w}}$ and $Ð$ to be determined.

Dynamic Light Scattering (DLS). Nanoparticles diameter $\left(D_{\mathrm{z}}\right)$ was measured by dynamic light scattering with a Nano ZS from Malvern with a detector angle of $173^{\circ}$ (back scattering) at $25^{\circ} \mathrm{C}$

\section{Synthetic Procedures}

Synthesis of Im-MePEG ${ }_{2000}$. In a dry three-neck round bottom flask under Argon atmosphere, 1,1'-carbonyldiimidazole (1.62 g, $0.010 \mathrm{~mol}, 2$ equiv.) and $15 \mathrm{~mL}$ of anhydrous DCM were introduced. A solution of $\mathrm{MePEG}_{2000}(5 \mathrm{~g}, 0.005 \mathrm{~mol}, 1$ equiv.) in $15 \mathrm{~mL}$ of anhydrous DCM 
was added dropwise into the solution of CDI during $30 \mathrm{~min}$. The reaction was carried out for $6 \mathrm{~h}$ at room temperature under magnetic stirring. DCM was then evaporated under vacuum. Finally, the polymer was precipitated three times in diethyl ether and dried under high vacuum. Yield $=89 \% .{ }^{1} \mathrm{H}$ NMR $\left(300 \mathrm{MHz}, \mathrm{CDCl}_{3}\right) \delta 8.15(\mathrm{~s}, 1 \mathrm{H}, \mathrm{N}-\mathrm{CH}=\mathrm{N}), 7.44(\mathrm{~s}, 1 \mathrm{H}, \mathrm{N}-$ $\mathrm{CH}=\mathrm{CH}), 7.1(\mathrm{~s}, 1 \mathrm{H}, \mathrm{N}-\mathrm{CH}=\mathrm{CH}), 4.58-4.52\left(\mathrm{~m}, 2 \mathrm{H}, \mathrm{N}-\mathrm{COO}-\mathrm{CH}_{2}\right), 3.63\left(\mathrm{~s}, 174 \mathrm{H}, \mathrm{O}-\mathrm{CH}_{2^{-}}\right.$ $\mathrm{CH}_{2}-\mathrm{O}$ ), 3.36 (s, 3H, O-CH $\mathbf{H}_{3}$ ) (Figure S1). $M_{\mathrm{n}}=2300$ g.mol ${ }^{-1}$. SEC (PEG calibration): $M_{\mathrm{n}}=$ 1800 g.mol ${ }^{-1} . Ð=1.03$.

Synthesis of $P E G_{2000} V E$. In a dry round bottom flask under Argon atmosphere, Im-MePEG 2000 (3.0 g, 0.001 mol, 1 equiv.) was solubilized in $10 \mathrm{~mL}$ of anhydrous DCM. Then aminopropylvinylether (140 $\mu \mathrm{L}, 0.001 \mathrm{~mol}, 1$ equiv.) was added under magnetic stirring. The reaction was carried out at $30{ }^{\circ} \mathrm{C}$ for $40 \mathrm{~h}$. Then DCM was evaporated under vacuum. Finally, the polymer was precipitated three times in diethyl ether and dried under high vacuum. Yield $=82 \% .{ }^{1} \mathrm{H}$ NMR $\left(300 \mathrm{MHz}, \mathrm{CDCl}_{3}\right) \delta 6.45\left(\mathrm{dd}, J=6.5 \mathrm{~Hz}, 1 \mathrm{H}, \mathrm{H}_{2} \mathrm{C}=\mathrm{CH}-\mathrm{O}\right), 4.23-$ $4.18\left(\mathrm{~m}, 2 \mathrm{H}, \mathrm{N}-\mathrm{COO}-\mathrm{CH}_{2}\right), 4.00\left(\mathrm{dd}, J=4.0 \mathrm{~Hz}, 2 \mathrm{H}, \mathbf{H}_{2} \mathrm{C}=\mathrm{CH}-\mathrm{O}\right), 3.89-3.54(\mathrm{~m}, 2 \mathrm{H}, \mathrm{O}-$

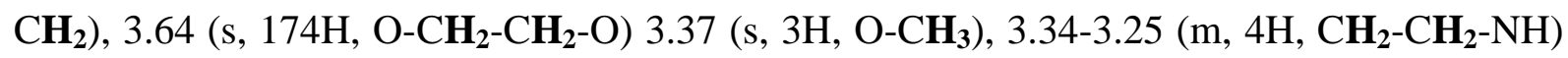
(Figure S2). $M_{\mathrm{n}}=2400 \mathrm{~g} \cdot \mathrm{mol}^{-1} \cdot \mathrm{SEC}\left(\mathrm{PEG}\right.$ calibration): $M_{\mathrm{n}}=1850 \mathrm{~g} \cdot \mathrm{mol}^{-1} \cdot \bigoplus=1.02$. Synthesis of poly(2-methylene-1,3-dioxepane)-co-(2-chloroethyl vinyl ether) (P(MDO-co$C E V E)$ ). A typical copolymerization procedure $\left(f_{\mathrm{CEVE}, 0}=0.1\right.$, expt. $\left.\mathbf{C 1}\right)$ is as follow. In a 7 mL-vial, fitted with a rubber septum and a magnetic stirrer bar, a mixture of MDO (1.5 g, $13.1 \mathrm{mmol}), \mathrm{CEVE}(155.6 \mathrm{mg}, 1.5 \mathrm{mmol})$ and the initiator DEAB (113.2 $\mathrm{mg}, 0.4 \mathrm{mmol})$ was submitted to three freeze/thaw cycles and then backfilled with Argon. The mixture was then immersed in a preheated oil bath at $70{ }^{\circ} \mathrm{C}$ for $8 \mathrm{~h}$. MDO conversion was calculated by ${ }^{1} \mathrm{H}$ NMR, using the methylene protons of $\mathrm{MDO}(\mathrm{s}, 3.5 \mathrm{ppm})$ and the $\mathrm{CH}_{2}$ protons in $\alpha$-position to the ester group in the copolymer (t, $4.1 \mathrm{ppm})$. The copolymer was then precipitated once in cold cyclohexane and dried under high vacuum. Final composition of the purified copolymer 
was calculated using ${ }^{1} \mathrm{H}$ NMR (Figure S3) by comparing the signal at $4.0 \mathrm{ppm}$ (MDO units, $\mathrm{CH}_{2}$ in $\alpha$-position to the ester group) to the signal at 3.4-3.5 ppm (CEVE units, corresponding to $5 \mathrm{H}$ of CEVE). The macromolecular characteristics $\left(M_{\mathrm{n}}\right.$ and $\left.Ð\right)$ were determined by SEC (PMMA calibration) (Figure S4). The same procedure was followed by adapting the amount of reactants for $f_{\mathrm{CEVE}, 0}=0.2$ (expt. C2) [MDO (1.5 g, $\left.13.1 \mathrm{mmol}\right), \mathrm{CEVE}(350.1 \mathrm{mg}, 3.3$ mmol) and DEAB (127.3 mg, $0.5 \mathrm{mmol})]$ and $f_{\mathrm{CEVE}, 0}=0.3$ (expt. C3) [MDO (1.5 g, 13.1 mmol), CEVE (600 mg, $5.6 \mathrm{mmol})$ and DEAB (145.5 mg, $0.6 \mathrm{mmol})]$.

Synthesis of poly(2-methylene-1,3-dioxepane)-co-(tetra(ethylene glycol) methyl vinyl ether) $(P(M D O-c o-T E G V E))$. A typical copolymerization procedure $\left(f_{\mathrm{TEGVE}, 0}=0.2\right.$, expt. T1 $)$ is as follow. In a $7 \mathrm{~mL}$-vial, fitted with a rubber septum and a magnetic stirrer bar, a mixture of MDO (660.9 mg, $5.8 \mathrm{mmol})$, TEGVE (339.1 mg, $1.4 \mathrm{mmol})$ and the initiator DEAB (18.7 $\mathrm{mg}, 0.07 \mathrm{mmol}$ ) was submitted to three freeze/thaw cycles and then backfilled with Argon. The mixture was then immersed in a preheated oil bath at $70{ }^{\circ} \mathrm{C}$ for $24 \mathrm{~h}$. MDO conversion was calculated by ${ }^{1} \mathrm{H}$ NMR, using the methylene protons of MDO (s, $3.5 \mathrm{ppm}$ ) and the $\mathrm{CH}_{2}$ protons in $\alpha$-position to the ester group in the copolymer ( $\mathrm{t}, 4.1 \mathrm{ppm})$. The copolymer was then precipitated once in cold cyclohexane and dried under high vacuum. Final composition of pure copolymer was calculated using ${ }^{1} \mathrm{H}$ NMR (Figure S5) by comparing the signal at 4.0 ppm (MDO units, $\mathrm{CH}_{2}$ in $\alpha$-position to the ester group) to the signal at 3.4-3.5 ppm (TEGVE units, terminal $\left.\mathrm{CH}_{3}\right)$. The macromolecular characteristics $\left(M_{\mathrm{n}}\right.$ and $\left.Ð\right)$ were determined by SEC (PMMA calibration) (Figure S6). The same procedure was followed by adapting the amount of reactants for $f_{\text {TEGVE, } 0}=0.25$ (expt. T2) [MDO $(593.7 \mathrm{mg}, 5.2 \mathrm{mmol})$, TEGVE (406.3 mg, $1.7 \mathrm{mmol})$ and DEAB (17.9 $\mathrm{mg}, 0.07 \mathrm{mmol})]$.

Synthesis of poly[(2-methyle-1,3-dioxepane)-co-(2-azidoethoxy)ethene] (P(MDO-co- $\left.N_{3} V E\right)$. A typical procedure is as follow. In a 7-mL vial fitted with a rubber septum and a magnetic stirrer bar, a mixture of P(MDO-co-CEVE) (expt. C1, $M_{\mathrm{n}}=12600$ g.mol ${ }^{-1}, 100 \mathrm{mg}, 7.9 \times 10^{-5}$ 
mol), sodium azide $\left(29 \mathrm{mg}, 4.4 \times 10^{-4} \mathrm{~mol}\right)$ in $5 \mathrm{~mL}$ of anhydrous DMF was degassed under stirring by argon bubbling for $15 \mathrm{~min}$ at room temperature. The mixture was then immersed in a preheated oil bath at $80{ }^{\circ} \mathrm{C}$ for $24 \mathrm{~h}$. After, the mixture was allowed to cool to room temperature, THF was added and the resulting precipitated salts were filtered off twice using a $0.2 \mu \mathrm{m}$ PTFE syringe filter. The copolymer was dried under high vacuum. The same procedure was followed by adapting the amount of reactants: [expt. C2: $M_{\mathrm{n}}=8800 \mathrm{~g} \cdot \mathrm{mol}^{-1}$, $\left.100 \mathrm{mg}, 1.1 \times 10^{-5} \mathrm{~mol}\right)$, sodium azide $\left(58 \mathrm{mg}, 8.9 \times 10^{-4} \mathrm{~mol}\right)$ in $5 \mathrm{~mL}$ of anhydrous DMF] and [expt. C3: $M_{\mathrm{n}}=7000$ g.mol $\left.{ }^{-1}, 1.4 \times 10^{-5} \mathrm{~mol}\right)$, sodium azide $\left(86 \mathrm{mg}, 1.32 \times 10^{-3} \mathrm{~mol}\right)$ in 5 mL of anhydrous DMF].

Synthesis of poly(2-methylene-1,3-dioxepane)-co-(PEG $\left.{ }_{750} V E\right)$ (P(MDO-co-PEG $\left.\left.G_{750} V E\right)\right)$. A typical CuAAc procedure (expt. $\mathbf{C 1}_{\mathbf{1 0 0}}$ ) is as follow. In a $7 \mathrm{~mL}$ vial fitted with a rubber septum and a magnetic stirrer bar, a mixture of $\mathrm{P}\left(\mathrm{MDO}-\mathrm{co}-\mathrm{N}_{3} \mathrm{EVE}\right)\left(M_{\mathrm{n}}=13200 \mathrm{~g} \cdot \mathrm{mol}^{-1}, 45 \mathrm{mg}, 3.4\right.$ x $\left.10^{-6} \mathrm{~mol}\right)$, alkyne-MePEG $750\left(30 \mathrm{mg}, 4.0 \times 10^{-5} \mathrm{~mol}\right)$ in $2.5 \mathrm{~mL}$ of anhydrous DMF was degassed under stirring by argon bubbling for $30 \mathrm{~min}$. Then $\mathrm{CuBr}\left(11.5 \mathrm{mg}, 8.0 \times 10^{-5} \mathrm{~mol}\right)$ was added and the solution was degassed further for $10 \mathrm{~min}$. Finally, PMDETA (33 $\mu \mathrm{L}, 1.6 \mathrm{x}$ $10^{-4} \mathrm{~mol}$ ) was added and the reaction mixture was stirred for $20 \mathrm{~h}$ at $40{ }^{\circ} \mathrm{C}$. The reaction mixture was passed through a small column of neutral alumina to remove copper residues. Then DMF was evaporated under vacuum. Finally, the copolymer was precipitated once in a mixture of cyclohexane/diethyl ether 1:1 and dried under high vacuum before analysis by ${ }^{1} \mathrm{H}$ NMR and SEC (Figure S7 and S8). The same procedure was followed by adapting the amount of reactants for (expt. C1 $\left.\mathbf{1}_{\mathbf{5 0}}\right)$ [P(MDO-co-N $\left.\mathrm{N}_{3} \mathrm{EVE}\right)\left(M_{\mathrm{n}}=13200 \mathrm{~g} \cdot \mathrm{mol}^{-1}, 45 \mathrm{mg}, 3.4 \times 10^{-6}\right.$ mol), alkyne-MePEG $750\left(15 \mathrm{mg}, 2.0 \times 10^{-5} \mathrm{~mol}\right), 2.5 \mathrm{~mL}$ of anhydrous DMF, $\mathrm{CuBr}(5.7 \mathrm{mg}$, $\left.4.0 \times 10^{-5} \mathrm{~mol}\right)$ and PMDETA $\left.\left(16.7 \mu \mathrm{L}, 8.0 \times 10^{-5} \mathrm{~mol}\right)\right]$, (expt. C1 20$)$ [P(MDO-co-N $\left.\mathrm{N}_{3} \mathrm{EVE}\right)$ $\left(M_{\mathrm{n}}=13200 \mathrm{~g} \cdot \mathrm{mol}^{-1}, 150 \mathrm{mg}, 1.1 \times 10^{-5} \mathrm{~mol}\right)$, alkyne-MePEG $750\left(20 \mathrm{mg}, 2.6 \times 10^{-5} \mathrm{~mol}\right), 7.5$ $\mathrm{mL}$ of anhydrous DMF, CuBr $\left(7.5 \mathrm{mg}, 5.2 \times 10^{-5} \mathrm{~mol}\right)$ and PMDETA $\left(22 \mu \mathrm{L}, 10.4 \times 10^{-5}\right.$ 
mol)], (expt. C2 $\left.{ }_{100}\right)$ [P(MDO-co-N $\left.\mathrm{N}_{3} \mathrm{EVE}\right)\left(M_{\mathrm{n}}=10900\right.$ g.mol $\left.{ }^{-1}, 100 \mathrm{mg}, 9.2 \times 10^{-6} \mathrm{~mol}\right)$, alkyne-MePEG $750\left(135 \mathrm{mg}, 1.8 \times 10^{-4} \mathrm{~mol}\right), 5 \mathrm{~mL}$ of anhydrous $\mathrm{DMF}, \mathrm{CuBr}(51.6 \mathrm{mg}, 3.6 \times$ $\left.10^{-4} \mathrm{~mol}\right)$ and PMDETA $\left.\left(150 \mu \mathrm{L}, 7.2 \times 10^{-4} \mathrm{~mol}\right)\right]$, (expt. C2 $\left.\mathbf{5 0}\right)\left[\mathrm{P}\left(\mathrm{MDO}-c o-\mathrm{N}_{3} \mathrm{EVE}\right)\left(M_{\mathrm{n}}=\right.\right.$ 10900 g.mol $\left.{ }^{-1}, 45 \mathrm{mg}, 4.1 \times 10^{-6} \mathrm{~mol}\right)$, alkyne-MePEG $750\left(30 \mathrm{mg}, 4.0 \times 10^{-5} \mathrm{~mol}\right), 2.5 \mathrm{~mL}$ of anhydrous DMF, CuBr (11.5 mg, $\left.8.0 \times 10^{-5} \mathrm{~mol}\right)$ and PMDETA $\left.\left(33 \mu \mathrm{L}, 1.6 \times 10^{-4} \mathrm{~mol}\right)\right]$, (expt. C2 20) [P(MDO-co-N N $_{3}$ EVE) $\left(M_{\mathrm{n}}=10900\right.$ g. $\left.\mathrm{mol}^{-1}, 80 \mathrm{mg}, 7.3 \times 10^{-6} \mathrm{~mol}\right)$, alkyne$\operatorname{MePEG}_{750}\left(21 \mathrm{mg}, 2.8 \times 10^{-5} \mathrm{~mol}\right), 4 \mathrm{~mL}$ of anhydrous DMF, CuBr $\left(8.0 \mathrm{mg}, 5.6 \times 10^{-5} \mathrm{~mol}\right)$ and PMDETA $\left.\left(23.4 \mu \mathrm{L}, 11.2 \times 10^{-5} \mathrm{~mol}\right)\right]$, (expt. C3 $\left.\mathbf{3}_{\mathbf{1 0 0}}\right)$ [P(MDO-co-N $\left.\mathrm{N}_{3} \mathrm{EVE}\right)\left(M_{\mathrm{n}}=(9300\right.$ g.mol $\left.{ }^{-1}, 70 \mathrm{mg}, 7.5 \times 10^{-6} \mathrm{~mol}\right)$, alkyne-MePEG $750\left(142.5 \mathrm{mg}, 1.9 \times 10^{-4} \mathrm{~mol}\right), 3.5 \mathrm{~mL}$ of anhydrous DMF, CuBr (54.5 mg, $\left.3.8 \times 10^{-4} \mathrm{~mol}\right)$ and PMDETA $\left.\left(158 \mu \mathrm{L}, 7.6 \times 10^{-4} \mathrm{~mol}\right)\right]$, (expt. C3 $\left.3_{50}\right)$ [P(MDO-co-N $\left.\mathrm{N}_{3} \mathrm{EVE}\right)\left(M_{\mathrm{n}}=9300 \mathrm{~g} \cdot \mathrm{mol}^{-1}, 50 \mathrm{mg}, 5.4 \times 10^{-6} \mathrm{~mol}\right)$, alkyne$\mathrm{MePEG}_{750}\left(48.8 \mathrm{mg}, 6.5 \times 10^{-5} \mathrm{~mol}\right), 2.5 \mathrm{~mL}$ of anhydrous DMF, CuBr $\left(18.6 \mathrm{mg}, 1.3 \times 10^{-4}\right.$ mol) and PMDETA $\left.\left(54 \mu \mathrm{L}, 2.6 \times 10^{-4} \mathrm{~mol}\right)\right]$ and (expt. $\left.\mathbf{C 3}_{\mathbf{2 0}}\right)\left[\mathrm{P}\left(\mathrm{MDO}-c o-\mathrm{N}_{3} \mathrm{EVE}\right)\left(M_{\mathrm{n}}=\right.\right.$ 9300 g.mol $\left.{ }^{-1}, 100 \mathrm{mg}, 1.0 \times 10^{-5} \mathrm{~mol}\right)$, alkyne-MePEG $750\left(40 \mathrm{mg}, 5.3 \times 10^{-5} \mathrm{~mol}\right), 5 \mathrm{~mL}$ of anhydrous DMF, $\mathrm{CuBr}\left(14.3 \mathrm{mg}, 1.0 \times 10^{-4} \mathrm{~mol}\right)$ and PMDETA $\left.\left(42 \mu \mathrm{L}, 2.0 \times 10^{-4} \mathrm{~mol}\right)\right]$.

Synthesis of poly(2-methylene-1,3-dioxepane)-co-(VE-PEG $\left.G_{2000}\right)\left(P\left(M D O-c o-P E G_{2000} V E\right)\right)$. In a $7 \mathrm{~mL}$-vial, fitted with a rubber septum and a magnetic stirrer bar, a mixture of MDO (379 mg, $3.3 \mathrm{mmol}), \mathrm{PEG}_{2000} \mathrm{VE}(371 \mathrm{mg}, 0.18 \mathrm{mmol})$ and the initiator DEAB $(27 \mathrm{mg}$, $0.1 \mathrm{mmol}$ ) was degassed by Argon bubbling for $30 \mathrm{~min}$. The mixture was then immersed in a preheated oil bath at $70{ }^{\circ} \mathrm{C}$. MDO conversion was calculated by ${ }^{1} \mathrm{H}$ NMR spectroscopy using the methylene protons of $\mathrm{MDO}(\mathrm{s}, 3.5 \mathrm{ppm})$ and the $\mathrm{CH}_{2}$ protons in $\alpha$-position to the ester group in the copolymer $(\mathrm{t}, 4.1 \mathrm{ppm})$. The copolymer was precipitated once in a cold mixture of cyclohexane/diethyl ether 1:1 and dried under vacuum. The resulting solid was solubilized in distillate water $\left(1.7 \mathrm{mg} \cdot \mathrm{mL}^{-1}\right)$ and this solution was dialysed over a $6-8 \mathrm{kD}$ cut-off membrane for 8 days. Finally, the solution was freeze-dried for 24 h. Final composition of 
purified copolymer was calculated using ${ }^{1} \mathrm{H}$ NMR (Figure S9) by comparing the signal at 4.0 ppm (MDO units, $\mathrm{CH}_{2}$ in $\alpha$-position to the ester group) to the signal at $3.4 \mathrm{ppm}\left(\mathrm{PEG}_{2000} \mathrm{VE}\right.$ units, methoxy protons). The macromolecular characteristics $\left(M_{\mathrm{n}}\right.$ and $\left.Ð\right)$ were determined by SEC (PMMA calibration) (Figure S10).

Synthesis of poly(2-methylene-1,3-dioxepane) (PMDO). In a $7 \mathrm{~mL}$-vial, fitted with a rubber septum and a magnetic stirrer bar, a mixture of MDO (362.4 mg, $3.2 \mathrm{mmol})$ and the initiator DEAB (25.8 mg, $0.1 \mathrm{mmol}$ ) was degassed by Argon bubbling for $30 \mathrm{~min}$. The mixture was then immersed in a preheated oil bath at $70{ }^{\circ} \mathrm{C}$. After $1 \mathrm{~h}$, the polymer was precipitated once in cold cyclohexane and dried under vacuum. Conversion in MDO after $1 \mathrm{~h}=20 \%$. SEC (PMMA calibration): $M_{\mathrm{n}}=11400 \mathrm{~g} \cdot \mathrm{mol}^{-1} . Ð=1.4$.

\section{Nanoparticles Preparation}

Nanoparticles were prepared by the nanoprecipitation technique. ${ }^{32}$ For P(MDO-co-CEVE) (C1-C3), $2.0 \mathrm{mg}$ of copolymer were dissolved in $670 \mu \mathrm{L}$ of THF and this solution was added dropwise to $2 \mathrm{~mL}$ of a solution of Pluronic ${ }^{\circledR}(1 \mathrm{wt} . \%$ in MilliQ water) under stirring. THF was then evaporated at room temperature using a Rotavapor. Intensity-averaged diameter $\left(D_{\mathrm{z}}\right)$ measurements were carried out in triplicate. The same procedure was applied for P(MDO-coTEGVE) (T1 and T2) and copolymers functionalized by CuAAC P(MDO-co-PEG $\left.{ }_{750} \mathrm{VE}\right)$ $\left(\mathbf{C 1}_{\mathbf{2 0}}, \mathbf{C 1}_{\mathbf{5 0}}, \mathbf{C 2} \mathbf{2 0}_{20}\right)$. Briefly, $2.0 \mathrm{mg}$ of copolymer was dissolved in $670 \mu \mathrm{L}$ of THF and this solution was added dropwise to $2 \mathrm{~mL}$ of MilliQ water under stirring. Similarly, for P(MDOco- $\left.\mathrm{PEG}_{2000} \mathrm{VE}\right)$ with $45 \mathrm{wt} \%$ of $\mathrm{PMDO}, 2.7 \mathrm{mg}$ of $\mathrm{P}\left(\mathrm{MDO}-c o-\mathrm{PEG}_{2000} \mathrm{VE}\right)$ and $2.6 \mathrm{mg}$ of PMDO were dissolved in $1.8 \mathrm{~mL}$ of THF. This solution was added dropwise to $4.8 \mathrm{~mL}$ of MilliQ water under stirring. For P(MDO-co-PEG $\left.{ }_{2000} \mathrm{VE}\right)$ with 80 wt.\% of PMDO, $1.5 \mathrm{mg}$ of $\mathrm{P}\left(\mathrm{MDO}-\mathrm{co}-\mathrm{PEG}_{2000} \mathrm{VE}\right)$ and $6.5 \mathrm{mg}$ of PMDO were dissolved in THF and this solution was added dropwise in $8 \mathrm{~mL}$ of MilliQ water under stirring. 
For stability study, the different samples were either let in water or diluted in PBS to reach a final concentration of $0.5 \mathrm{mg} \cdot \mathrm{mL}^{-1}$. Samples were kept at $4{ }^{\circ} \mathrm{C}$ and let warm to room temperature before each measurement.

\section{Degradation Experiments}

Accelerated Degradation. In a $7 \mathrm{~mL}$-vial, $50 \mathrm{mg}$ of copolymer was dissolved in $2.5 \mathrm{~mL}$ of THF. After solubilization, $2.5 \mathrm{~mL}$ of sodium hydroxide solution $(\mathrm{NaOH}, 1 \%)$ in methanol was added. The mixture was stirred at room temperature. Samples $(1 \mathrm{~mL})$ were periodically taken, immediately dried under high vacuum and $2 \mathrm{~mL}$ of chloroform was added. The organic solution was washed three time with an aqueous solution of $\mathrm{HCl} 1 \mathrm{M}$, then filtered twice with $0.2 \mu \mathrm{m}$ PTFE filter to remove the salts. Solvent was then removed under reduced pressure and degradation products were analysed by SEC (PMMA calibration).

Long-Term Hydrolytic Degradation. The following method was applied for each kinetic point (i.e., 3, 6, 9 and 12 months). In a $7 \mathrm{~mL}$-vial, $20 \mathrm{mg}$ of copolymer was poured into $2 \mathrm{~mL}$ of PBS $1 \mathrm{X}$ and mechanically stirred in an orbital shaker at $37^{\circ} \mathrm{C}$. At the kinetic given point, the vial was withdrawn from the shaker, and the content was freeze-dried. $2 \mathrm{~mL}$ of chloroform was then added, allowing removal of buffer salts by filtration. Finally, the solvent was removed under reduced pressure, and the degradation products were analysed by SEC (PMMA calibration).

Enzymatic Degradation. The following method was applied for each kinetic point (i.e., 24 and $48 \mathrm{~h}$ ). In a $7 \mathrm{~mL}$-vial, $20 \mathrm{mg}$ of copolymer was poured into $2 \mathrm{~mL}$ of PBS $1 \mathrm{X}$ and mechanically stirred in an orbital shaker at $37{ }^{\circ} \mathrm{C}$. Briefly, $20 \mathrm{mg}$ of copolymer was solubilized in $500 \mu \mathrm{L}$ of THF and added dropwise to $2 \mathrm{~mL}$ of PBS. THF was evaporated and

lipase from Candida antarctica $\left(100 \mathrm{U} \cdot \mathrm{mL}^{-1}\right)$ was added to the mixture. At the given point the vial was withdrawn from the shaker, and the content was freeze dried. $2 \mathrm{~mL}$ of chloroform 
was then added, allowing removal of buffer salt and immobilized enzymes by filtration. Finally, the solvent was removed under reduced pressure, and the degradation products were analysed by SEC (PMMA calibration).

\section{Cytotoxicity Evaluation}

Cell lines and cell culture. Human endothelial umbilical vein cells (HUVEC) and murine macrophage-monocyte cells (J774.A1) were maintained as recommended. HUVEC cells were grown in Dulbecco's Modified Eagle Medium (DMEM) high glucose supplemented with 10 \% Foetal Bovine Serum (FBS), penicillin $\left(100 \mathrm{U}_{\mathrm{mL}} \mathrm{m}^{-1}\right)$ and streptomycin $\left(100 \mathrm{U} \cdot \mathrm{mL}^{-1}\right)$. J774.A1 cells were grown in Roswell Park Memorial Institute medium (RPMI) 1640 supplemented with $10 \%$ heat-inactivated $\left(56{ }^{\circ} \mathrm{C}, 30 \mathrm{~min}\right) \mathrm{FBS}$, penicillin $\left(100 \mathrm{U} \cdot \mathrm{mL}^{-1}\right)$ and streptomycin $\left(100 \mathrm{U} \cdot \mathrm{mL}^{-1}\right)$. Cells were maintained in a humid atmosphere at $37{ }^{\circ} \mathrm{C}$ with $5 \% \mathrm{CO}_{2}$.

Cytotoxicity study. In vitro cytotoxicity activity of the copolymers was evaluated on the two cell lines using 3-[4,5-dimethylthiazol-2-yl]-3,5-diphenyltetrazolium bromide (MTT) test. Cells were seeded in $100 \mu \mathrm{L}$ of growth medium $\left(8 \times 10^{4}\right.$ cells. $\left.\mathrm{mL}^{-1}\right)$ in 96 -well microliter plates and preincubated for $24 \mathrm{~h}$. After appropriate dilutions, $100 \mu \mathrm{L}$ of copolymer solution in cell culture medium was added over the cells and incubated for $72 \mathrm{~h}$. At the end of incubation period, $20 \mu \mathrm{L}$ of MTT solution (5 mg.mL ${ }^{-1}$ in PBS) were then added to each well. The plates were incubated $1.5 \mathrm{~h}$ at $37{ }^{\circ} \mathrm{C}$ and the medium was removed. $200 \mu \mathrm{L}$ of DMSO was then added to each well to dissolve the precipitates. Absorbance was measured at $570 \mathrm{~nm}$ using a plate reader (Metertech $\Sigma$ 960, Fisher Bioblock, Illkirch, France). The percentage of surviving cells was calculated as the absorbance ratio of treated cells to untreated cells. All experiments were set up in sextuplicate to determine means and SD. 


\section{Results and Discussion}

\section{Rationale of the copolymer synthesis}

A small library of copolymers was obtained by conventional radical copolymerization between 2-methylene-1,3-dioxepane (MDO) and vinyl ether derivatives of different nature. The idea was to prepare copolymers of variable aqueous solubility (i.e., hydrophobic, amphiphilic or water-soluble) and to formulate them into nanoparticles (Figure 2). To obtain stable nanoparticles and ensure efficient colloidal stability, hydrophobic copolymers were formulated in the presence of surfactants (Figure 2a, Path 1) conversely to amphiphilic copolymers (surfactant-free formulation, Figure 2a, Path 2 and Figure 2b), whereas watersoluble copolymers were blended with hydrophobic PMDO prior formulation without surfactant (Figure 2c). These three different procedures have been routinely employed with polyesters to prepare biodegradable nanoparticles for drug delivery. Indeed, PLA can be formulated in the presence of (macro)molecular surfactants such as sodium cholate ${ }^{33}$ or Pluronics ${ }^{34}$ whereas PLA- $b$-PEG diblock copolymer can be, depending on its amphiphilicity, either directly formulated into nanoparticles ${ }^{35}$ or blended with PLA prior the formulation step. $^{36}$ 
(a)

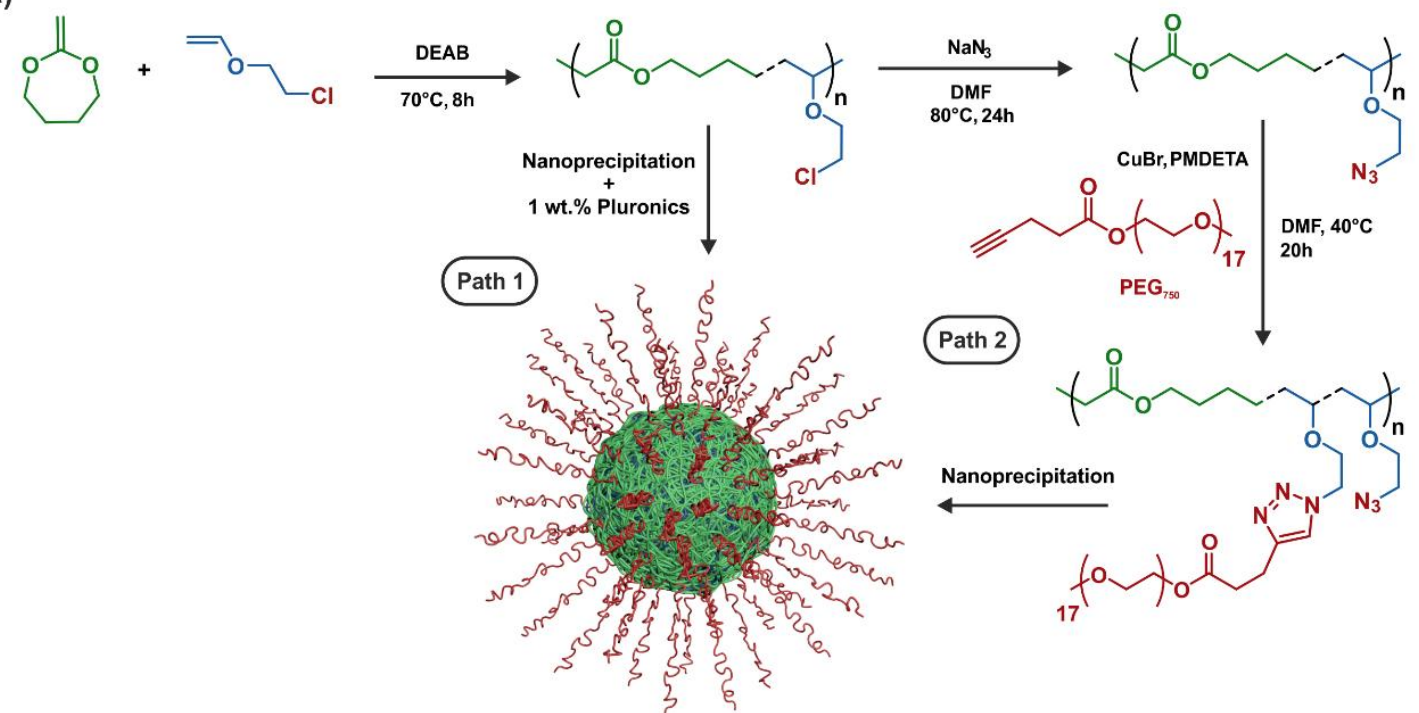

(b)

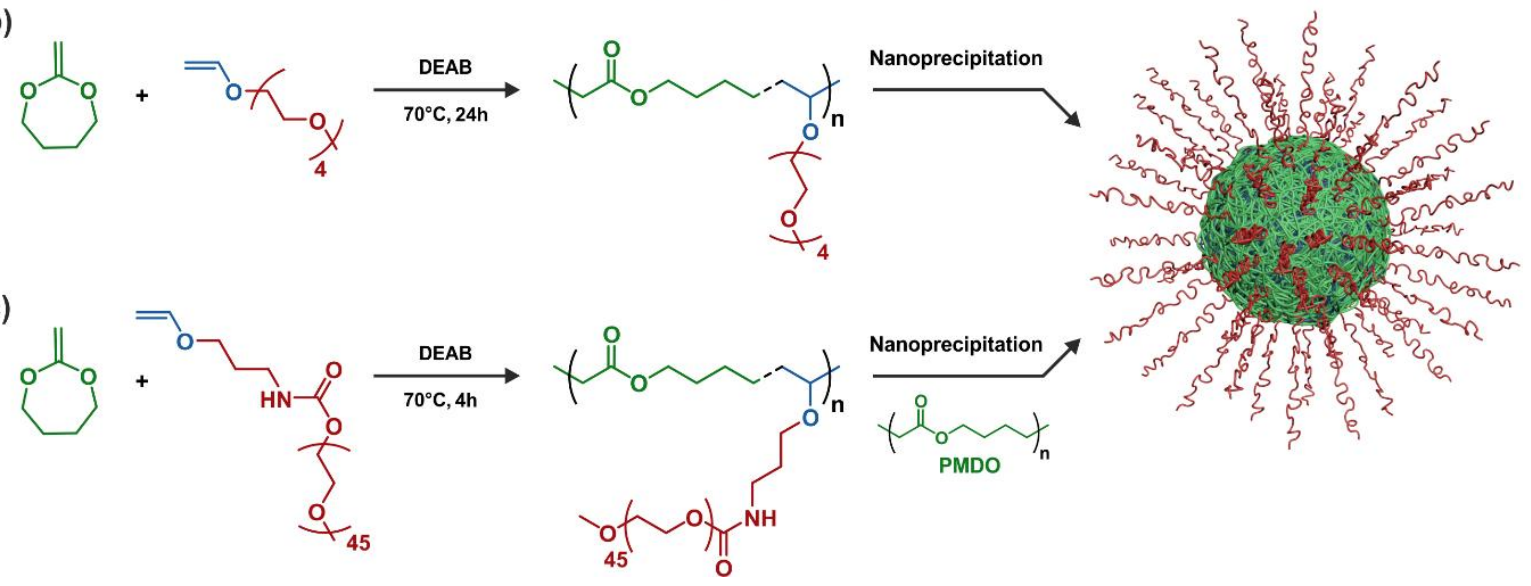

Figure 2. Synthesis of: (a) $\mathrm{P}(\mathrm{MDO}-\mathrm{co}-\mathrm{CEVE})$ copolymers and nanoprecipitation in the presence of Pluronic surfactants (Path 1), or P(MDO-co- $\mathrm{N}_{3} \mathrm{VE}$ ) copolymers by azidation of $\mathrm{P}(\mathrm{MDO}-\mathrm{co}-\mathrm{CEVE})$ followed by grafting of alkyne- $\mathrm{PEG}_{750}$ by $\mathrm{CuAAC}$ and nanoprecipitation (Path 2); (b) P(MDO-co-TEGVE) and nanoprecipitation and (c) $\mathrm{P}\left(\mathrm{MDO}-\mathrm{co}-\mathrm{PEG}_{2000} \mathrm{VE}\right.$ ) and co-nanoprecipitation with PMDO.

\section{Copolymer synthesis}

As for hydrophobic copolymers, 2-chloroethyl vinyl ether (CEVE) was copolymerized by rROP with different initial molar fractions of $\mathrm{MDO}\left(f_{\mathrm{MDO}, 0}=0.9-0.7\right)$ at $70{ }^{\circ} \mathrm{C}$ in bulk with $\mathrm{DEAB}$ as the initiator to give $\mathrm{P}(\mathrm{MDO}-\mathrm{co}-\mathrm{CEVE})$ copolymers $(\mathbf{C 1}-\mathbf{C 3}$, Table 1 and Figure 2a, Path 1). Final $M_{\mathrm{n}}$ after $8 \mathrm{~h}$ of copolymerization was $\sim 9000$ g.mol ${ }^{-1}$ with broad molar mass distribution $(Ð \geq 2)$ in agreement with the free-radical process. As expected from the 
favourable reactivity ratios, ${ }^{30}$ final molar fractions of $\mathrm{MDO}, F_{\mathrm{MDO}}$, were in excellent agreement with the corresponding $f_{\mathrm{MDO}, 0}$ values, assessing the nearly ideal copolymerization.

To design amphiphilic $\mathrm{P}(\mathrm{MDO}-\mathrm{co}$-VE) copolymers, the idea was to incorporate PEG segments in the copolymer structure. To this end, two different routes were explored: (i) the direct copolymerization between MDO and tetra(ethylene glycol) methyl vinyl ether (TEGVE) (Figure 2b) and (ii) the post-functionalization of $\mathrm{P}\left(\mathrm{MDO}-\mathrm{co}-\mathrm{N}_{3} \mathrm{VE}\right)$ with alkynePEG $_{750}$ by copper(I)-catalyzed azide alkyne cycloaddition (CuAAC) ${ }^{35,37,38}$ (Figure 2a, Path 2). Copolymerization between MDO and TEGVE was performed under similar experimental conditions with $f_{\mathrm{MDO}, 0}=0.80$ and 0.75 and resulted in $\mathrm{P}(\mathrm{MDO}-\mathrm{co}$-TEGVE) copolymers $(\mathrm{T} 1$ and T2, Table 1) with $M_{\mathrm{n}}=9200$ and $7100 \mathrm{~g} \cdot \mathrm{mol}^{-1}$, dispersities around 1.5 and a fairly good agreement between $f_{\mathrm{MDO}, 0}$ and $F_{\mathrm{MDO}}$ values ( 0.76 and 0.66 , respectively). As for the postfunctionalization approach, $\mathrm{P}(\mathrm{MDO}-\mathrm{co}-\mathrm{CEVE}) \mathbf{C 1 - C 3}$ were first reacted at $80{ }^{\circ} \mathrm{C}$ for $24 \mathrm{~h}$ with sodium azide to quantitatively replace chlorine atoms by azide moieties, leading to $\mathrm{P}\left(\mathrm{MDO}-\mathrm{co}-\mathrm{N}_{3} \mathrm{VE}\right)$ copolymers. Subsequently, CuAAC with $\mathrm{CuBr} / \mathrm{PMDETA}$ as the catalytic system was performed with alkyne-PEG 750 in $\mathrm{DMF}$ at $40{ }^{\circ} \mathrm{C}$ for $20 \mathrm{~h}$ by targeting variable coupling ratios (i.e., 20, 50 and 100 mol.\% with respect to the total amount of azide groups), resulting in nine different $\mathrm{P}\left(\mathrm{MDO}-\mathrm{co}-\mathrm{PEG}_{750} \mathrm{VE}\right)$ copolymers $\left(\mathbf{C x}_{\mathbf{2 0}}, \mathbf{C x}_{\mathbf{5 0}}\right.$ and $\mathbf{C x}_{\mathbf{1 0 0}}$, with $\mathrm{x}=$ $1-3$, see Table 1$)$.

A water-soluble copolymer was also obtained by direct copolymerization between $\mathrm{MDO}$ and a $\mathrm{PEG}_{2000} \mathrm{VE}$ macromonomer $\left(f_{\mathrm{MDO}, 0}=0.95\right)$ for $4 \mathrm{~h}$ under otherwise identical experimental conditions (P1, Table 1 and Figure $2 \mathrm{c}) . \mathrm{PEG}_{2000} \mathrm{VE}$ was synthesized by coupling aminopropylvinyl ether with $\mathrm{MePEG}_{2000}$ through CDI coupling. ${ }^{39,40}$ The resulting P(MDO-co$\mathrm{PEG}_{2000} \mathrm{VE}$ ) was purified by dialysis to remove unreacted monomer and gave $M_{\mathrm{n}}=13000$ g.mol ${ }^{-1}, Ð=1.4$ and a final molar fraction of MDO of 0.76 . 
Table 1. Experimental Conditions and Macromolecular Characteristics of the Different Copolymers Synthesized in this Study.

\begin{tabular}{|c|c|c|c|c|c|c|c|}
\hline Expt. & VE & $f_{\mathrm{MDO}, 0}{ }^{a}$ & $F_{\mathrm{MDO}}^{b}$ & $F_{\mathrm{PEG}}^{c}$ & $\begin{array}{l}\text { MDO conv. } \\
(\%)^{d} / \text { time } \\
\text { (h) }\end{array}$ & $\begin{array}{c}M_{\mathrm{n}, \mathrm{exp} .} \\
\left.(\text { g.mol })^{-1}\right)^{e}\end{array}$ & $\boldsymbol{\boxplus}^{e}$ \\
\hline $\mathrm{C1}$ & CEVE & 0.90 & 0.90 & & $70 / 8$ & 12600 & 3.30 \\
\hline $\mathrm{C1}_{100}$ & $\mathrm{PEG}_{750} \mathrm{VE}$ & - & - & 0.09 & & 4200 & 1.53 \\
\hline $\mathrm{C1}_{50}$ & $\mathrm{PEG}_{750} \mathrm{VE}$ & - & - & 0.05 & & 13800 & 1.30 \\
\hline $\mathrm{C1}_{20}$ & $\mathrm{PEG}_{750} \mathrm{VE}$ & - & - & 0.02 & & 8500 & 1.80 \\
\hline C2 & CEVE & 0.80 & 0.83 & & $46 / 8$ & 8800 & 2.45 \\
\hline$C 2_{100}$ & $\mathrm{PEG}_{750} \mathrm{VE}$ & - & - & 0.17 & & 5500 & 1.50 \\
\hline $\mathrm{C} 2_{50}$ & $\mathrm{PEG}_{750} \mathrm{VE}$ & - & - & 0.10 & & 7800 & 1.12 \\
\hline $\mathrm{C2}_{20}$ & $\mathrm{PEG}_{750} \mathrm{VE}$ & - & - & 0.06 & & 9000 & 1.09 \\
\hline $\mathrm{C3}$ & CEVE & 0.70 & 0.73 & & $18 / 8$ & 7000 & 1.97 \\
\hline $\mathrm{C3}_{100}$ & $\mathrm{PEG}_{750} \mathrm{VE}$ & - & - & 0.27 & & 2800 & 1.55 \\
\hline $\mathrm{C3}_{50}$ & $\mathrm{PEG}_{750} \mathrm{VE}$ & - & - & 0.17 & & 11300 & 1.30 \\
\hline $\mathrm{C3}_{20}$ & $\mathrm{PEG}_{750} \mathrm{VE}$ & - & - & 0.07 & & 9500 & 1.10 \\
\hline T1 & TEGVE & 0.80 & 0.76 & & $49 / 24$ & 9200 & 1.50 \\
\hline $\mathbf{T} 2$ & TEGVE & 0.75 & 0.66 & & $35 / 24$ & 7100 & 1.44 \\
\hline P1 & $\mathrm{PEG}_{2000} \mathrm{VE}$ & 0.95 & 0.76 & & $34 / 4$ & 13000 & 1.40 \\
\hline
\end{tabular}

${ }^{a}$ Initial molar fraction of MDO in the monomer feed. ${ }^{b}$ Molar fraction of MDO in the purified copolymer determined by ${ }^{1} \mathrm{H}$ NMR. ${ }^{c}$ Determined by ${ }^{1} \mathrm{H}$ NMR by assessing the coupling yield using the $\mathrm{CH}_{2}$ in $\alpha$-position to the triazole ring (4.4 ppm) and the $\mathrm{CH}_{2}$ in $\alpha$-position to ester group in the copolymer (4.1 ppm) ${ }^{30 d}$ Calculated by ${ }^{1} \mathrm{H}$ NMR before purification. ${ }^{e}$ Determined by SEC in chloroform with PMMA standards.

\section{Formulation and colloidal characteristics}

Hydrophobic P(MDO-co-CEVE) copolymers C1-C3 were formulated into nanoparticles in the presence of surfactants using the nanoprecipitation technique (Figure 2a, Path 1). ${ }^{32}$ As surfactants, we selected the Pluronic family as they are widely employed ${ }^{41}$ for drug delivery purposes and also because having a PEG-based coating at the surface of the nanoparticles could be advantageous in terms of biocompatibility and stealth properties. ${ }^{42-46}$ Pluronics are triblock copolymers, with a hydrophobic central block of poly(propylene oxide) (PPO), two hydrophilic external blocks of poly(ethylene oxide) (PEO), and whose solution/colloidal 
properties can be finely tuned by changing the PPO and PEO block lengths. ${ }^{45}$ Five Pluronics were tested: L64, F68, F108, P123 and F127; giving three different lengths of PPO and five different lengths of PEO (Table S1). P(MDO-co-CEVE) nanoparticles were formulated at 1 $\mathrm{mg} \cdot \mathrm{mL}^{-1}$ in presence of $1 \mathrm{wt} . \%$ of each Pluronic.

Overall, all formulations gave nanoparticle suspensions with intensity-averaged diameters $\left(D_{\mathrm{z}}\right)$ ranging from 175 to $360 \mathrm{~nm}$ and particle size distributions between 0.13 and 0.25 (Table 2 and Figure S11a-c). No noticeable influence of the copolymer composition neither of the length of the PPO block on the nanoparticle size was observed. However, increasing: (i) the molar fraction of CEVE whatever the surfactant or (ii) the weight percentage of the PEO for a fixed PPO block length, resulted in a noticeable increase of $D_{\mathrm{z}}$. For instance, average $D_{\mathrm{z}}$ were 200, 230 and $240 \mathrm{~nm}$ for nanoparticles C1, C2 and C3, respectively. Interestingly, whereas nanoparticles stabilized by Pluronic F68 and F108 gave, on average, higher $D_{\mathrm{z}}$ values than those stabilized by Pluronic L64, P123 or F127, their polydispersity indexes were among the lowest $(\sim 0.16)$.

Table 2. Colloidal Characteristics of P(MDO-co-CEVE) Nanoparticles Stabilized by Pluronic Surfactants. $^{a}$

\begin{tabular}{ccccccc}
\hline & \multicolumn{2}{c}{ C1 } & \multicolumn{2}{c}{ C2 } & \multicolumn{2}{c}{ C3 } \\
\hline Pluronic & $\begin{array}{c}\boldsymbol{D}_{z} \\
(\mathbf{n m})\end{array}$ & PSD & $\begin{array}{c}\boldsymbol{D}_{z} \\
(\mathbf{n m})\end{array}$ & PSD & $\begin{array}{c}\boldsymbol{D}_{z} \\
(\mathbf{n m})\end{array}$ & PSD \\
\hline L64 & 200 & 0.17 & 210 & 0.20 & 215 & 0.13 \\
$\mathbf{F 6 8}$ & 230 & 0.20 & 250 & 0.17 & 360 & 0.12 \\
$\mathbf{F 1 0 8}$ & 200 & 0.17 & 260 & 0.22 & 230 & 0.13 \\
P123 & 175 & 0.25 & 200 & 0.24 & 180 & 0.21 \\
$\mathbf{F 1 2 7}$ & 210 & 0.22 & 210 & 0.19 & 200 & 0.16 \\
\hline
\end{tabular}

${ }^{a}$ Determined by DLS. 
Given copolymers T1 and T2 contained hydrophilic TEG pending units (24 and 34 mol.\%, respectively), and thus a certain amphiphilicity, they were nanoprecipitated into nanoparticles (1 mg.mL ${ }^{-1}$ ) without any additional surfactant (Figure 2b). Nanoparticles of $D_{\mathrm{z}}=220 \mathrm{~nm}$ $(\mathrm{PSD}=0.14)$ and $170 \mathrm{~nm}(\mathrm{PSD}=0.16)$, respectively, were successfully formed (Figure S11d). Note that T2, which contained the highest amount of TEGVE units, led to nanoparticles with the best colloidal properties (i.e., lowest $D_{\mathrm{z}}$ and PSD).

Similarly, $\mathrm{P}\left(\mathrm{MDO}-\mathrm{co}-\mathrm{PEG}_{750} \mathrm{VE}\right)$ copolymers obtained by CuAAC between P(MDO$\left.c o-\mathrm{N}_{3} \mathrm{VE}\right)$ and alkyne- $\mathrm{PEG}_{750}$ were also directly nanoprecipitated in aqueous solution without any surfactant (Figure 2a, Path 2). Whereas copolymers with $100 \%$ coupling with alkynePEG $\mathrm{F}_{750}\left(\mathrm{Cx}_{100}\right)$ were totally water soluble, best nanoparticle formulations were obtained for intermediate coupling yields and/or low $\mathrm{PEG}_{750}$ contents $(<0.1 \mathrm{~mol} . \%)$, with $D_{\mathrm{z}}$ in the 130-150 nm range and very narrow PSD (0.06-0.15) indicating efficient stabilization and promising colloidal features for use in drug delivery applications (Table 3 and Figure S11e).

Table 3. Colloidal Properties of Nanoparticles Obtained by CuAAC between P(MDO-co$\mathrm{N}_{3} \mathrm{VE}$ ) and Alkyne-PEG $\mathrm{P}_{750}{ }^{a}$

\begin{tabular}{ccccc}
\hline Expt. & $\begin{array}{c}\text { CuAAC coupling ratio } \\
(\boldsymbol{\%})\end{array}$ & $\boldsymbol{F}_{\mathbf{P E G 7 5 0}}{ }^{\boldsymbol{b}}$ & $\begin{array}{c}\boldsymbol{D}_{z} \\
(\mathbf{n m})\end{array}$ & PSD \\
\hline $\mathbf{C 1}_{\mathbf{2 0}}$ & 20 & 0.02 & 130 & 0.11 \\
$\mathbf{C 1}_{\mathbf{5 0}}$ & 50 & 0.05 & 145 & 0.06 \\
$\mathbf{C 2} 2_{\mathbf{2 0}}$ & 20 & 0.06 & 150 & 0.15 \\
\hline
\end{tabular}

${ }^{a}$ Determined by DLS. ${ }^{b}$ Determined by ${ }^{1} \mathrm{H}$ NMR spectroscopy.

Considering its too high water-solubility, likely because of the long $\mathrm{PEG}_{2000}$ chains, $\mathrm{P}(\mathrm{MDO}-$ co-PEG $\left.{ }_{2000} \mathrm{VE}\right) \mathbf{P 1}$ was fully water soluble and did not form nanoparticles by nanoprecipitation. However, successful formation of nanoparticles was obtained by nanoprecipitation of a mixture of $\mathbf{P 1}$ and PMDO, acting as the main constituent of the 
nanoparticle core (Figure 2c). By tuning the weight percentage of PMDO, the nanoparticle size was efficiently modified (Figure S11f). Indeed, with 80 wt. $\%$ PMDO, $D_{z}=290 \mathrm{~nm}$ (PSD $=0.22)$ whereas with 45 wt. $\%$ PMDO to $45 \%, D_{z}=160 \mathrm{~nm}(\mathrm{PSD}=0.12)$, the latter being in the good size window for drug delivery purposes.

Colloidal stability of a selection of nanoparticles was then assessed over a period of 14 days. Overall, no major change in size was observed for P(MDO-co-CEVE) nanoparticles except for nanoparticles C1-C3 stabilized by Pluronic F68, whose diameters significantly increased (Figure 3a-c). As for nanoparticles T1 and T2, the average diameter and the PSD stayed relatively constant over time (Figure 3d) and nanoparticles were perfectly stable up to 7 days before a few amounts of precipitate started to form, likely because of too short EO chain lengths to confer efficient stabilization in the long run. Therefore, these nanoparticles would likely exhibit enhanced colloidal stability if copolymers $\mathbf{T 1}$ and $\mathbf{T} 2$ would be formulated in the presence of surfactant. As for $\mathrm{P}\left(\mathrm{MDO}-\mathrm{co}-\mathrm{PEG}_{750} \mathrm{VE}\right)$ nanoparticles, they gave very high colloidal stability as the average diameter stayed nearly constant up to 6 months with a still narrow particle size distribution $(\mathrm{PSD}=0.07)$. $\mathrm{P}(\mathrm{MDO}-\mathrm{co}$ $\mathrm{PEG}_{2000} \mathrm{VE}$ /PMDO nanoparticles also exhibit high colloidal stability as shown by the constant diameters and the low PSD over time, especially for the formulation obtained with 45 wt.\% PMDO, which also exhibited stability in PBS at least up to 11 days (Figure 3e,f). 

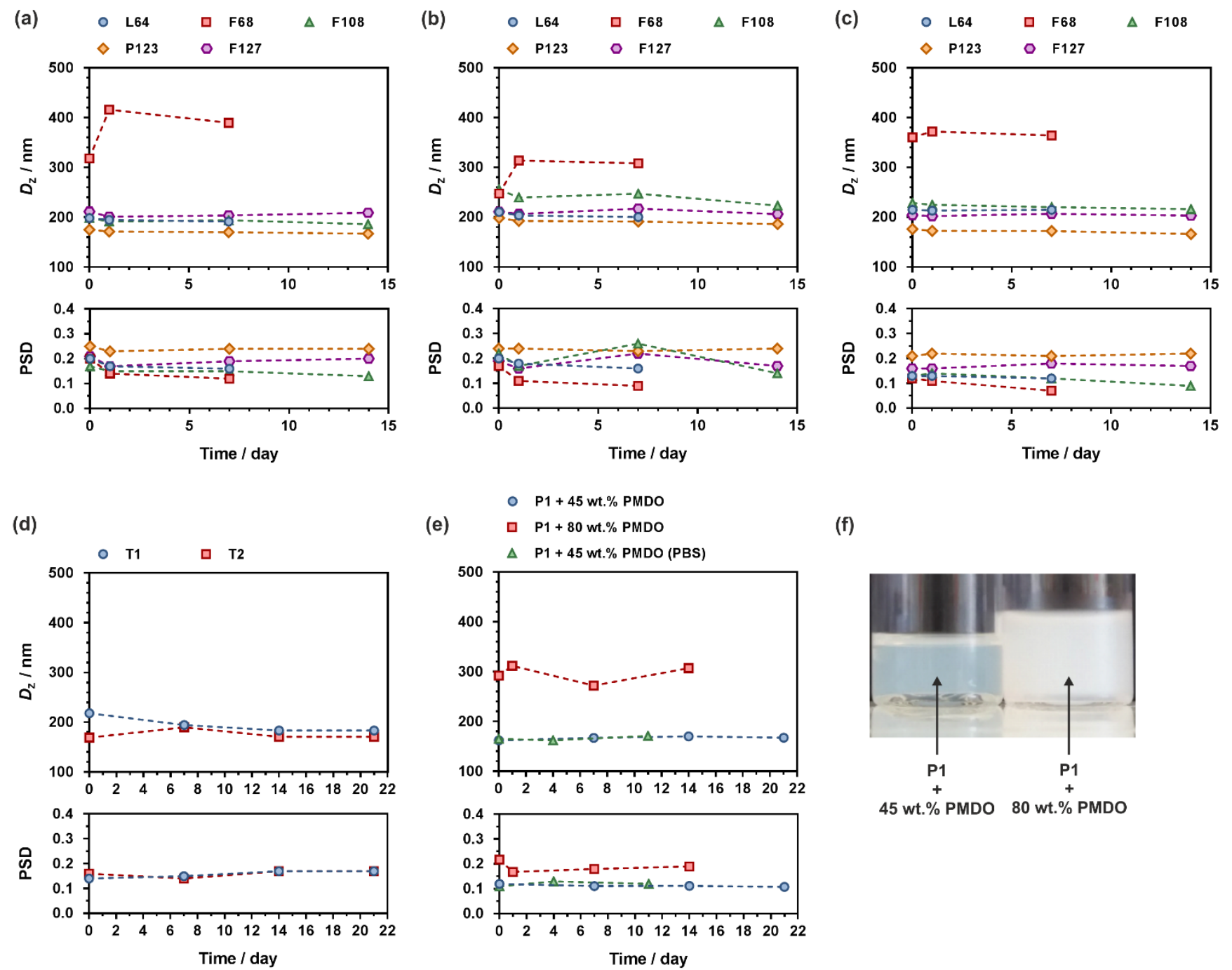

(f)

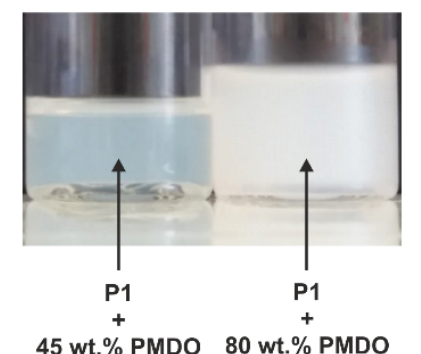

Figure 3. Evolution with time of the average diameter $\left(D_{z}\right)$ and the particle size distribution (PSD) of P(MDO-co-VE) nanoparticles. (a) P(MDO-co-CEVE) (C1) stabilized by Pluronics. (b) P(MDO-co-CEVE) (C2) stabilized by Pluronics. (c) P(MDO-co-CEVE) (C3) stabilized by Pluronics. (d) P(MDO-co-TEGVE) (T1 and T2) in water. (e) P(MDO-co-PEG $\mathrm{P}_{2000} \mathrm{VE}$ ) (P1) co-nanoprecipitated with PMDO in water. (f) Picture of nanoparticles obtained by co-nanoprecipitation of $\mathrm{P}\left(\mathrm{MDO}-\mathrm{co}-\mathrm{PEG}_{2000} \mathrm{VE}\right) \mathbf{P 1}$ depending on the amount of PMDO. 


\section{Degradation study}

Assessing degradation of a new materials intended to be used for biomedical applications is of prime importance. Degradation was therefore comprehensively studied under three different conditions: (i) hydrolytic degradation under accelerated conditions (1 wt.\% $\mathrm{NaOH}$ ); (ii) hydrolytic degradation under physiological conditions (PBS 1X, pH 7.4, $37{ }^{\circ} \mathrm{C}$ ) and (iii) enzymatic degradation in presence of lipases (Candida antarctica).

Hydrolytic degradation under accelerated conditions was conducted on P(MDO-coCEVE) (C1-C3) and P(MDO-co-TEGVE) (T1 and T2). Even though these conditions poorly reflect the biological environment, they are useful and routinely used to confirm the presence of labile groups in the copolymer backbone. The degradation was followed for $1 \mathrm{~h}$ at room temperature in THF with 1 wt. $\% \mathrm{NaOH}$ in methanol. In all cases, clear shifts of SEC chromatograms toward very low $M_{\mathrm{n}}\left(560-680\right.$ g.mol ${ }^{-1}$ for $\mathbf{C 1}-\mathbf{C 3}$ and $970-980$ g.mol ${ }^{-1}$ for T1 and T2) were obtained (Figure S12, 4a and Table 4). Degradations ranged from 86 to 96\% and were influenced by the amount of MDO in the copolymer; the higher $F_{\mathrm{MDO}}$, the greater the $M_{\mathrm{n}}$ decrease. Such nearly complete degradations were the result of the high molar fractions of $\mathrm{MDO}$ in the copolymers $\left(F_{\mathrm{MDO}}=0.66-0.90\right)$. This was made possible by the quasi-random copolymerization of CKA and VE derivatives, as opposed to copolymerizations between CKA and methacrylic esters, whose unfavorable reactivity ratios lead to copolymers composed of isolated CKA units and consecutive methacrylic ester units, the average chain length of which is governed by $F_{\text {CKA }}$. 
Table 4. Features of the Accelerated Hydrolytic Degradation of the Different P(MDO-coCEVE) and P(MDO-co-TEGVE) Copolymers. ${ }^{a}$

\begin{tabular}{ccccccccc}
\hline expt. & VE & $F_{\mathrm{MDO}}{ }^{b}$ & $\begin{array}{c}\text { theo. } M_{\mathrm{n}, \infty}{ }^{c} \\
\left(\mathrm{~g} . \mathrm{mol}^{-1}\right)\end{array}$ & $\begin{array}{c}\text { exp. } M_{\mathrm{n}}{ }^{d} \\
\left(\mathrm{~g} \cdot \mathrm{mol}^{-1}\right)\end{array}$ & $\begin{array}{c}M_{\mathrm{n}} \\
\mathrm{decrease}^{e} \\
(\%)\end{array}$ & $\begin{array}{c}M_{\mathrm{n}, \infty}{ }^{f} \\
\left(\mathrm{~g} \cdot \mathrm{mol}^{-1}\right)\end{array}$ & $\begin{array}{c}\mathrm{t}_{1 / 2}{ }^{f} \\
(\mathrm{~min})\end{array}$ & $\begin{array}{c}\text { initial deg. rate } \\
\left(\mathrm{g} \cdot \mathrm{mol}^{-1} \cdot \mathrm{min}^{-1}\right)^{f}\end{array}$ \\
\hline C1 & CEVE & 0.90 & 330 & 560 & -96 & 690 & 1.31 & 6300 \\
C2 & CEVE & 0.80 & 330 & 630 & -93 & 820 & 1.21 & 4600 \\
C3 & CEVE & 0.70 & 330 & 680 & -90 & 950 & 1.52 & 2800 \\
T1 & TEGVE & 0.76 & 520 & 970 & -90 & 1000 & 1.91 & 3000 \\
T2 & TEGVE & 0.66 & 520 & 980 & -86 & 1100 & 1.31 & 3200 \\
\hline
\end{tabular}

${ }^{a}$ Degradation was performed for $1 \mathrm{~h}$ at room temperature in THF with $1 \% \mathrm{NaOH}$ in methanol. ${ }^{b}$ Molar fraction of MDO in the copolymer determined by ${ }^{1} \mathrm{H}$ NMR. ${ }^{c}$ Calculated according to: $n \times \mathrm{MW}_{\mathrm{VE}}+\mathrm{MW}_{\mathrm{MDO}}$ with $\mathrm{n}=2 .{ }^{47}$

${ }^{d}$ Determined by SEC. ${ }^{e} M_{\mathrm{n}}$ decrease after accelerated hydrolytic degradation calculated according to (exp. $M_{\mathrm{n}}-$ $\left.M_{\mathrm{n}, 0}\right) / M_{\mathrm{n}, 0}{ }^{f}$ Extracted from exponential decay fit. 

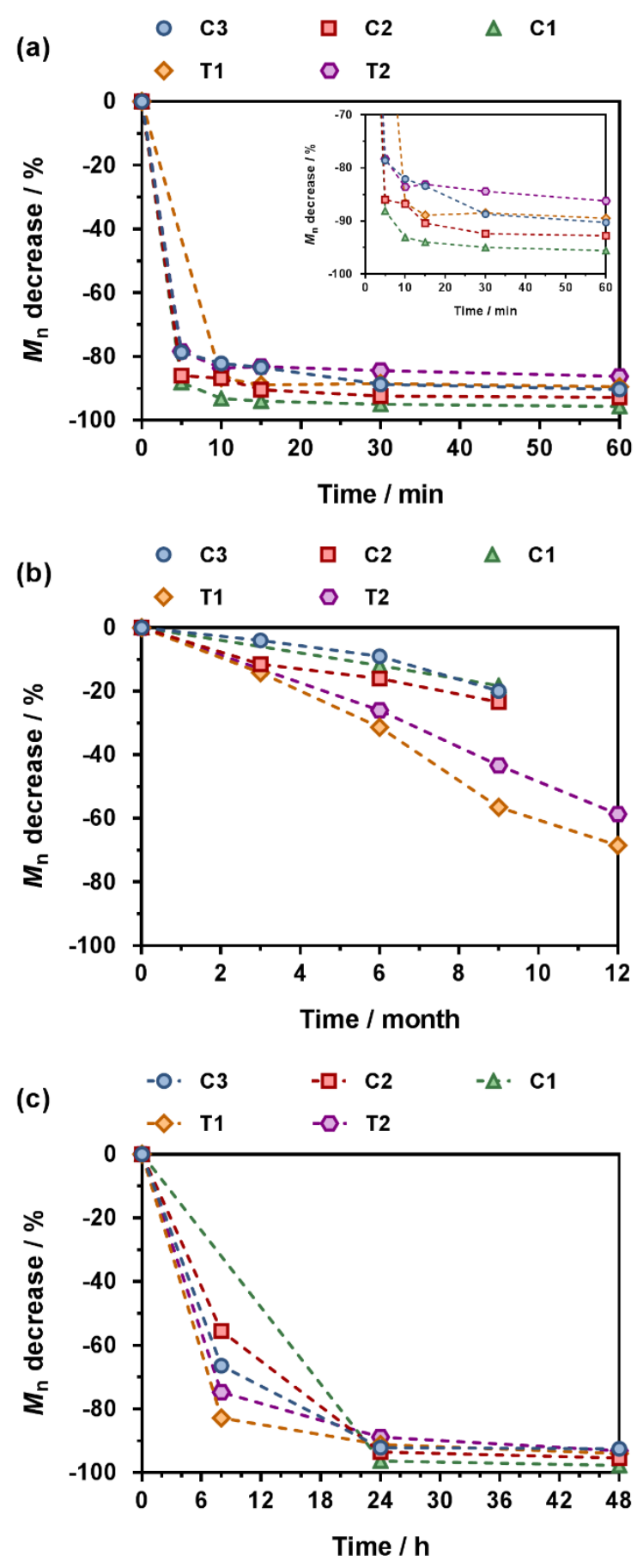

Figure 4. Evolution of the number-average molar mass, $M_{\mathrm{n}}$, with time during degradation of $\mathrm{P}(\mathrm{MDO}-$-co-CEVE) (C1-C3) and P(MDO-co-TEGVE) (T1, T2) copolymers under different conditions. (a) Accelerated hydrolytic degradation (THF with $1 \% \mathrm{NaOH}$ in methanol). Insert: zoom in between -70 and $-100 \%$ for the Y-axis. (b) Long-term hydrolytic degradation (PBS $1 \mathrm{x}, \mathrm{pH}=7.4,37^{\circ} \mathrm{C}$ ). (c) Enzymatic degradation (PBS 1x, pH = 7.4, with lipases (Candida antarctica $)$ at $\left.37{ }^{\circ} \mathrm{C}\right) . \bullet, \mathbf{C 1}\left(F_{\mathrm{MDO}}=0.90\right) ; \mathbf{\varpi}, \mathbf{C 2}\left(F_{\mathrm{MDO}}=0.83\right) ; \mathbf{\Delta}, \mathbf{C 3}\left(F_{\mathrm{MDO}}=0.73\right) ; \bullet, \mathbf{T 1}$ $\left(F_{\mathrm{MDO}}=0.76\right) ; \mathbf{O}, \mathbf{T} 2\left(F_{\mathrm{MDO}}=0.66\right)$. Dashed lines are only guides for the eye. 
To further characterize these new degradable copolymers, an exponential decay fit was then applied to each degradation kinetics to determine the $M_{\mathrm{n}}$ reached at equilibrium $\left(M_{\mathrm{n}, \infty}\right)$, the half-life time $\left(t_{1 / 2}\right)$ and the initial degradation rate (Figure $\mathrm{S} 13$ and Table 4$)$. While the different $M_{\mathrm{n}, \infty}$ values were very similar to their experimental counterparts, indicating equilibrium of the degradation reaction, $\mathrm{t}_{1 / 2}$ values as low as $\sim 1-2$ min and initial degradation rate ranging from 3000 to $6300 \mathrm{~g} \cdot \mathrm{mol}^{-1} \cdot \mathrm{min}^{-1}$ were obtained. These values may be important for potential benchmarking between different degradable materials by selecting the most appropriate ones for the desired applications.

To better mimic the physiological conditions in which these materials are intended to be used, $\mathrm{P}(\mathrm{MDO}-$ co-CEVE) (C1-C3) and $\mathrm{P}(\mathrm{MDO}-$-co-TEGVE) (T1, T2) copolymers were subjected to long-term hydrolytic degradation in PBS (1X, pH 7.4) under thermostated orbital shaking at $150 \mathrm{rpm}$ and $37^{\circ} \mathrm{C}$. The $M_{\mathrm{n}}$ evolution was monitored by SEC by withdrawing samples at given time points (i.e., 3, 6, 9 and 12 months). As for the accelerated hydrolytic degradation, a shift toward lower $M_{\mathrm{n}}$ was observed in each case (Figure S14), although on a much longer time frame as expected, with a similar $M_{\mathrm{n}}$ decrease vs. $F_{\mathrm{MDO}}$ trend (Figure $4 \mathrm{~b}$ ). Interestingly, TEGVE-based copolymers $\mathbf{T 1}$ and $\mathbf{T} 2$ led to a faster degradation rate with a $M_{\mathrm{n}}$ decrease of $\sim 60-70 \%$ after 12 months, whereas CEVE-based copolymers C1-C3 degraded much slower with a $M_{\mathrm{n}}$ decrease of $\sim 20 \%$ after 9 months (Figure $4 \mathrm{~b}$ ). This result is explained by a difference of solubility from the two series of copolymers as $\mathbf{C 1}-\mathbf{C 3}$ are hydrophobic thus preventing efficient solvation of ester groups and their rapid hydrolysis, whereas TEGVE units from $\mathbf{T} 1$ and $\mathbf{T} 2$ provided enough hydrophilicity to allow good solvation of the copolymers and thus efficient cleavage of ester groups. Given degradation is still on going after 9-12 months, as shown by the negative slope of the degradation kinetics (Figure $4 b$ ), 
much lower $M_{\mathrm{n}}$, similar to those obtained under accelerated conditions, are likely to be obtained if the degradation is prolonged for a longer period of time.

From a comparative point of view with traditional polyesters, $\mathrm{P}(\mathrm{MDO}-\mathrm{co}$-CEVE) C1C3 led to similar degradation patterns than polycaprolactone (PCL) under identical degradation conditions, for which a $M_{\mathrm{n}}$ decrease of $\sim 20 \%$ after 3 months ${ }^{26}$ and of $\sim 30 \%$ after 9 months ${ }^{48}$ has been reported. This is likely the result of the structural similarity between PCL and PCL-like P(MDO-co-CEVE) copolymers, especially given their high MDO contents. As expected from their much higher water-solubility, copolymers $\mathbf{T 1}$ and $\mathbf{T} 2$ gave a faster degradation in between that of PCL and polylactide (PLA), whose $M_{\mathrm{n}}$ decrease is $\sim 80 \%$ after 9 months and nearly complete after 12 months. ${ }^{48,49}$

This is a very interesting feature of this copolymerization system as it is possible to tune/accelerate the degradation rate of a PCL-like copolymer obtained by a radical mechanism by: (i) adjusting the amount of MDO in the copolymer and (ii) incorporation of hydrophilic VE units.

Evolution of $\mathrm{pH}$ with time was also monitored during long-term hydrolytic degradation. Whereas $\mathrm{P}(\mathrm{MDO}-\mathrm{co}$-TEGVE) copolymers led to a decrease of $\mathrm{pH}$ down to $\sim 5$ after 12 months, similarly to PLA and PLGA, ${ }^{48,50,51} \mathrm{P}(\mathrm{MDO}-$ co-CEVE) copolymers led to nearly stable $\mathrm{pH}$ around 6.8 (Figure 5), like PCL. ${ }^{48} 3$ 


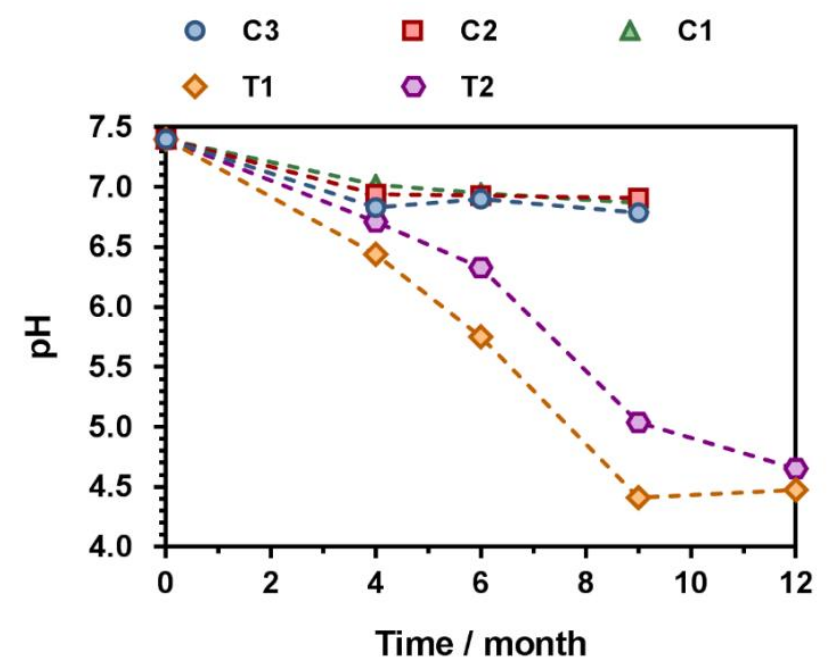

Figure 5. Evolution of $\mathrm{pH}$ with time during long-term hydrolytic degradation in PBS (1X, $\left.\mathrm{pH}=7.4,37^{\circ} \mathrm{C}\right)$ of MDO-based copolymers. $\bullet, \mathbf{C 1}\left(F_{\mathrm{MDO}}=0.90\right) ; \mathbf{\square}, \mathbf{C 2}\left(F_{\mathrm{MDO}}=0.83\right)$; $\mathbf{C 3}\left(F_{\mathrm{MDO}}=0.73\right) ; \diamond, \mathbf{T} 1\left(F_{\mathrm{MDO}}=0.76\right) ; \mathbf{\bullet}, \mathbf{T} 2\left(F_{\mathrm{MDO}}=0.66\right)$.

Developing new hydrolytically degradable, vinyl materials is already a promising step towards their safe use in biomedical applications, especially because it is considered as the main degradation mechanism of aliphatic polyesters ${ }^{52}$ in vivo. However, making them also susceptible to enzymatic degradation ${ }^{53}$ would also be advantageous as two distinct degradation pathways could be used, thus ensuring their excretion from the body after administration. $\mathrm{P}(\mathrm{MDO}-$ co-CEVE) (C1-C3) and $\mathrm{P}(\mathrm{MDO}-$-co-TEGVE) (T1, T2) copolymers were incubated in the presence of lipases from Candida antarctica, a subclass of esterases, ${ }^{27,54,55}$ in PBS at $37{ }^{\circ} \mathrm{C}$ and evolution of $M_{\mathrm{n}}$ was monitored over time. In all cases, SEC chromatograms exhibited clear shifts toward low $M_{\mathrm{n}}$ (Figure S15) and final $M_{\mathrm{n}}$ were as low as 320-480 g.mol ${ }^{-1}$ for C1-C3 and 400-430 g.mol ${ }^{-1}$ for T1 and T2 (Figure 4c and Table 5). These results accounted for a (nearly) complete degradation in the presence of enzyme whatever the copolymer used as decrease in $M_{\mathrm{n}}$ was in the $92-97 \%$ range. By plotting the evolution of $M_{\mathrm{n}}$ with time and applying an exponential decay fit, $M_{\mathrm{n}, \infty}$, the half-life time $\left(t_{1 / 2}\right)$ and initial degradation rate were determined (Figure S16 and Table 5). Interestingly, $t_{1 / 2}$ 
values of $\mathbf{T 1}$ and $\mathbf{T 2}$ were similar than those for $\mathbf{C 1}-\mathbf{C 3}$, despite their different nature/solubility.

Table 5. Features of the Enzymatic Degradation of $\mathrm{P}(\mathrm{MDO}-\mathrm{co}-\mathrm{CEVE})$ and $\mathrm{P}(\mathrm{MDO}-\mathrm{co}-$ TEGVE) Copolymers. ${ }^{a}$

\begin{tabular}{ccccccccc}
\hline expt. & VE & $F_{\text {MDO }}{ }^{b}$ & $\begin{array}{c}\text { theo. } M_{\mathrm{n}, \infty}{ }^{c} \\
\left(\mathrm{~g}^{-1} \mathrm{~mol}^{-1}\right)\end{array}$ & $\begin{array}{c}\text { exp. } M_{\mathrm{n}}{ }^{d} \\
\left(\mathrm{~g} . \mathrm{mol}^{-1}\right)\end{array}$ & $\begin{array}{c}M_{\mathrm{n}} \text { decrease }^{e} \\
(\%)\end{array}$ & $\begin{array}{c}M_{\mathrm{n}, \infty}{ }^{f} \\
\left(\mathrm{~g} \cdot \mathrm{mol}^{-1}\right)^{e}\end{array}$ & $\begin{array}{c}t_{1 / 2}{ }^{f} \\
(\mathrm{~h})\end{array}$ & $\begin{array}{c}\text { initial deg. rate } \\
\left(\mathrm{g} \cdot \mathrm{mol}^{-1} \cdot \mathrm{min}^{-1}\right)^{f}\end{array}$ \\
\hline C1 & CEVE & 0.90 & 330 & 320 & -97 & 320 & 3.9 & 2400 \\
C2 & CEVE & 0.80 & 330 & 420 & -95 & 200 & 6.3 & 1000 \\
C3 & CEVE & 0.70 & 330 & 580 & -92 & 500 & 4.4 & 1100 \\
T1 & TEGVE & 0.76 & 520 & 410 & -96 & 500 & 2.5 & 1800 \\
T2 & TEGVE & 0.66 & 520 & 440 & -94 & 550 & 3.3 & 1200 \\
\hline
\end{tabular}

${ }^{a}$ Degradation was performed for $48 \mathrm{~h}$ at $37{ }^{\circ} \mathrm{C}$ in PBS $(\mathrm{pH}=7.4)$ in the presence of Candida antarctica. ${ }^{b}$ Molar fraction of MDO in the copolymer determined by ${ }^{1} \mathrm{H}$ NMR. ${ }^{c}$ Calculated according to: $n \times \mathrm{MW}_{\mathrm{VE}}+\mathrm{MW}_{\mathrm{MDO}}$ with $\mathrm{n}=2 .{ }^{47}{ }^{d}$ Determined by SEC. ${ }^{e} M_{\mathrm{n}}$ decrease after enzymatic degradation calculated according to (exp. $M_{\mathrm{n}}-$ $\left.M_{\mathrm{n}, 0}\right) / M_{\mathrm{n}, 0 .}{ }^{f}$ Extracted from exponential decay fit.

Quantitative enzymatic degradation of $\mathrm{P}(\mathrm{MDO}-\mathrm{co}-\mathrm{VE})$ copolymers represented a very important result. Indeed, enzymatic degradation of copolymers obtained by rROP of methacrylic esters and CKA, one of the most studied radical ring-opening copolymerization systems so far, is often moderate likely because of the rather low amount of CKA units in the copolymer backbone (although impact of the CKA structure, in terms of steric hindrance and hydrophobicity, cannot not be ruled out). For instance, P(OEGMA-co-MPDL) copolymers $\left(F_{\mathrm{MPDL}}=0.27\right)$ incubated with Candida antarctica in $0.1 \mathrm{M} \mathrm{PBS}$ at $37^{\circ} \mathrm{C}$ for 1 week led to a $M_{\mathrm{n}}$ decrease of $\sim 15 \%$, whereas no degradation was observed with P(MMA-co-MPDL) copolymers. ${ }^{48}$ Also, $\mathrm{P}\left(\mathrm{MEO}_{2} \mathrm{MA}-\right.$-co-OEGMA-co-BMDO) terpolymers subjected to identical degradation conditions were not entirely degraded after $24 \mathrm{~h}$ (only $\sim 40 \%$ of the main-chain ester groups were hydrolysed $).{ }^{19}$ Similarly, copolymers based on MDO and PEGMA $\left(F_{\mathrm{MDO}}=\right.$ 
0.5) incubated in the presence of lipase from Pseudomonas cepacia led to uncompleted degradation (not quantified) even after 5 days at $37{ }^{\circ} \mathrm{C} .{ }^{28}$

\section{Cytotoxicity study}

Biomedical applications require the use of non-cytotoxic materials. In this context, preliminary in vitro cytotoxicity tests were performed on two different cell lines: human umbilical vein endothelial cells (HUVEC) and murine macrophages (J774.A1). These two cell lines are representative of important cell types in mammalian organisms. HUVEC are cells that line blood and lymphatic vessels and are among the first cells nanoparticles could encounter in the case of an intravenous injection. Therefore, this cell line is a relevant cell model for investigation preliminary cytotoxicity ${ }^{56,57} \mathrm{~J} 774$.A1 are macrophages that are highly involved in phagocytosis. Moreover, macrophages are the first line of defence in the immune response machinery. Hence, such a cell line is also relevant when investigating potential cytotoxicity of a synthetic materials intended to be administered intravenously.

MTT assays were performed to evaluate in vitro cytotoxicity of the nanoparticles with a maximal concentration of $0.1 \mathrm{mg} \cdot \mathrm{mL}^{-1}$; that is $\sim 5-10$ times more than $\mathrm{IC}_{50}$ values reported for poly(alkyl cyanoacrylate) nanoparticles,${ }^{58-60}$ which represent so far the only example of biodegradable vinyl nanoparticles that reached advanced clinical trials (Phase III) for anticancer therapy. ${ }^{61-63,64}$ PEGylated nanoparticles $\mathbf{T 1}, \mathbf{T} 2, \mathbf{C 1}_{\mathbf{2 0}}, \mathbf{C} \mathbf{1}_{\mathbf{5 0}}$ and $\mathbf{C 2}_{\mathbf{2 0}}$ were subjected to MTT assays as PEGylation resulting from grafted PEG chains to polymers/nanoparticles is preferable to surface adsorbed PEG polymers that can desorb, leaving holes in surface coverage where plasmatic proteins can bind. ${ }^{65}$ On HUVEC cells, except for nanoparticles $\mathbf{C 1}_{20}$ at $0.1 \mathrm{mg} \cdot \mathrm{mL}^{-1}$, cell viabilities were $>75 \%$ at 0.01 and 0.1 mg.mL $L^{-1}$ for all copolymers tested (Figure $6 \mathrm{a}, \mathrm{b}$ ). The highest cell viabilities at $0.1 \mathrm{mg} \cdot \mathrm{mL}^{-1}$ were obtained for nanoparticles made of copolymer $\mathbf{C} \mathbf{1}_{\mathbf{5 0}}$ and $\mathbf{C 2} \mathbf{2}_{\mathbf{2 0}}$, with values $\sim 84 \%$. Given 
their high cell viabilities, $\mathbf{C 1}_{\mathbf{5 0}}$ and $\mathbf{C 2}_{20}$ nanoparticles were also tested on J774.A1 cells, leading to high cell viabilities ranging from 75 to $96 \%$ (Figure 6c).
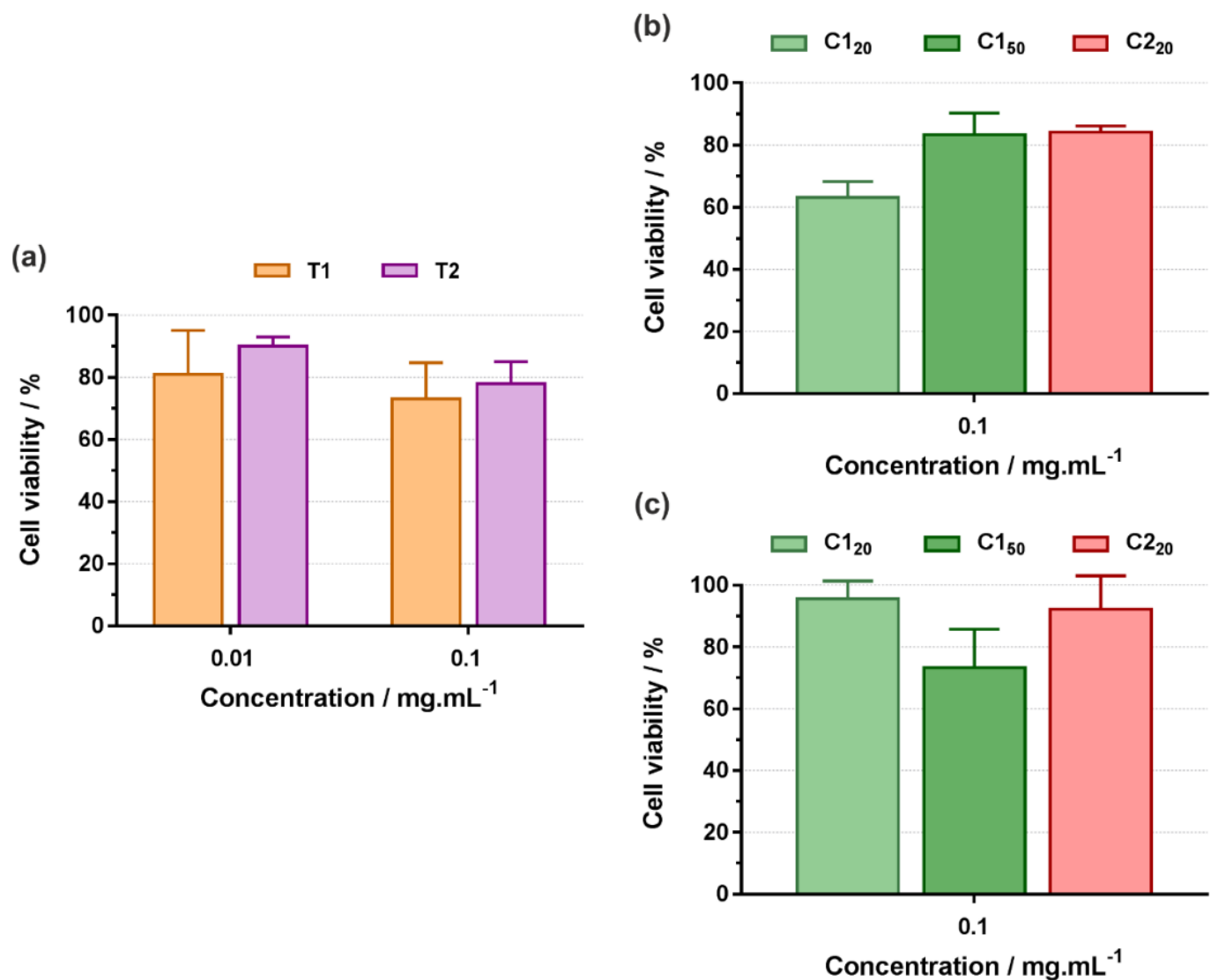

Figure 6. Cell viability (MTT assay) after incubation of: (a) HUVEC cells with P(MDO-coTEGVE) nanoparticles T1 and T2 at 0.01 and $0.1 \mathrm{mg}^{-1} \mathrm{~mL}^{-1}$; (b) HUVEC cells with P(MDOco-PEG ${ }_{750} \mathrm{VE}$ ) nanoparticles $\mathbf{C 1}_{\mathbf{2 0}}, \mathbf{C 1}_{\mathbf{5 0}}$ and $\mathbf{C 2}_{20}$ at $0.1 \mathrm{mg} \cdot \mathrm{mL}^{-1}$ and (c) J774.A1 with $\mathrm{P}(\mathrm{MDO}-$-co-PEG $750 \mathrm{VE})$ nanoparticles $\mathbf{C 1}_{\mathbf{2 0}}, \mathbf{C 1}_{\mathbf{5 0}}$ and $\mathbf{C 2}_{20}$ at $0.1 \mathrm{mg} . \mathrm{mL}^{-1}$. Results were expressed as percentages of absorption of treated cells $( \pm \mathrm{SD})$ in comparison with the values obtained from untreated control cells.

Given the water-solubility of $\mathrm{P}\left(\mathrm{MDO}-\mathrm{co}-\mathrm{PEG}_{2000} \mathrm{VE}\right)(\mathbf{P 1})$ and its use as efficient stabilizer for the formulation of PMDO nanoparticles, as shown earlier in this work, it was also tested for its potential cytotoxicity on HUVEC and J774.A1 cells up to very high concentrations (1 mg.mL $L^{-1}$ ) (Figure 7). The purpose of using such a very high concentration was only to overexpress any cytotoxic effect that could arise from the nature of the polymer and/or its 
degradation products. From the results, P1 led to high cell viabilities from 75 to $100 \%$ up to $0.2 \mathrm{mg} \cdot \mathrm{mL}^{-1}$ on both cell lines. Whereas significant cytotoxicity appeared at $0.5 \mathrm{mg} \cdot \mathrm{mL}^{-1}$ on J774.A1 cells, cell viabilities stayed constant at $\sim 75 \%$ on HUVEC cells up to a concentration as high as $1 \mathrm{mg} \cdot \mathrm{mL}^{-1}$, thus assessing the safe use of this copolymer for biomedical applications and especially as PEG-based coating for hydrophobic polymer nanoparticles.

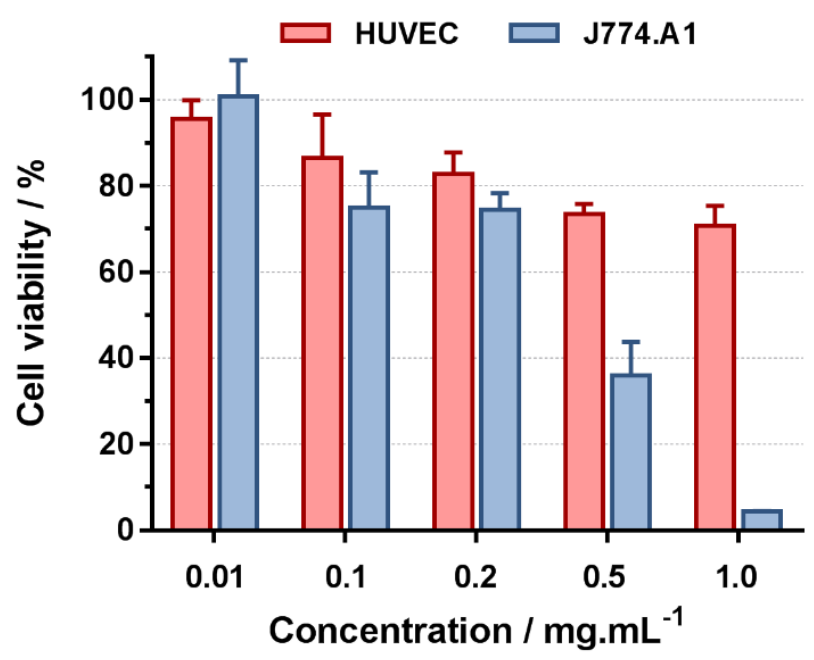

Figure 7. Cell viability (MTT assay) after incubation of HUVEC and J774.A1 cells at increasing concentrations from 0.01 to $1 \mathrm{mg} \cdot \mathrm{mL}^{-1}$ of $\mathrm{P}\left(\mathrm{MDO}-\mathrm{co}-\mathrm{PEG}_{2000} \mathrm{VE}\right)$ copolymer (P1). Results were expressed as percentages of absorption of treated cells ( \pm SD) in comparison with the values obtained from untreated control cells.

\section{Conclusion}

The nearly ideal free-radical ring-opening copolymerization between MDO and VE derivatives was employed to synthesize a small library of degradable vinyl copolymers with $M_{\mathrm{n}} \sim 10 \mathrm{~kg} \cdot \mathrm{mol}^{-1}$, high MDO molar fractions $\left(F_{\mathrm{MDO}}=0.7-0.9\right)$ and whose aqueous solubility was varied by changing the nature of the VE derivative: hydrophobic copolymers by using CEVE, amphiphilic copolymers by using TEGVE or via the grafting $\mathrm{PEG}_{750}$ chains onto a $\mathrm{P}\left(\mathrm{MDO}-\mathrm{co}-\mathrm{N}_{3} \mathrm{VE}\right)$ copolymer, or hydrophilic copolymers by using $\mathrm{PEG}_{2000} \mathrm{VE}$. The different 
copolymers were then formulated into nanoparticles by the nanoprecipitation technique using either PEG-based surfactants for hydrophobic copolymers, without surfactant for amphiphilic ones and blended with PMDO for hydrophilic copolymers. These different formulation options conducted to $\mathrm{P}(\mathrm{MDO}-\mathrm{co}-\mathrm{VE})$ nanoparticles, most of them exhibiting average diameters in the good window for drug delivery purposes and satisfying colloidal stability assessed for at least 2 weeks and up to 6 months. Degradation of the different copolymers was demonstrated in both accelerated, physiological and enzymatic conditions in presence of lipases. Importantly, whereas hydrolytic degradation in PBS proceeded similarly to that of PCL, incubation with lipases led to fast and complete degradation (ca. $-95 \%$ in $M_{\mathrm{n}}$ decrease), which, to the best of our knowledge, has never been reported in the literature for vinyl copolymers obtained by rROP between CKA and traditional vinyl monomers. Preliminary cytotoxicity assays were performed on two representative cell lines and led to high cell viabilities at concentrations higher than those reported for poly(alkyl cyanoacrylate) nanoparticles which represent so far the only example of vinyl polymer nanoparticles that reached advanced clinical trials against cancer.

In conclusion, this new copolymerization system can give access to PCL-like materials that degrade like PCL, but with the advantage of being easily functionalized through a broad range of commercially available or accessible vinyl ether derivatives. This is of high importance for the design of degradable and functional nanoparticles for drug delivery applications.

\section{Supplementary Information}

The Supporting Information is available free of charge on the ACS Publications website at DOI: < to be completed >. Macromolecular characteristic of Pluronics, ${ }^{1} \mathrm{H}$ NMR spectra and 
SEC chromatograms of the (co)polymers. DLS data of the nanoparticles. SEC chromatograms and evolution of the $M_{\mathrm{n}}$ with time of the copolymers during degradation.

\section{Acknowledgments}

We thank the French National Research Agency (ANR-15-CE08-0019) for the financial support of the PhD thesis of JT. The CNRS and the French Ministry of Research are also acknowledged for financial support.

\section{References}

1. Gross, R. A.; Kalra, B. Biodegradable Polymers for the Environment. Science 2002, 297, 803-807.

2. Siracusa, V.; Rocculi, P.; Romani, S.; Rosa, M. D. Biodegradable polymers for food packaging: a review. Trends Food Sci. Technol. 2008, 19, 634-643.

3. Tian, H.; Tang, Z.; Zhuang, X.; Chen, X.; Jing, X. Biodegradable synthetic polymers: Preparation, functionalization and biomedical application. Prog. Polym. Sci. 2012, 37, 237-280.

4. Nair, L. S.; Laurencin, C. T. Biodegradable polymers as biomaterials. Prog. Polym. Sci. 2007, 32, 762-798.

5. Williams, C. K. Synthesis of functionalized biodegradable polyesters. Chem. Soc. Rev. 2007, 36, 1573-1580.

6. Lecomte, P.; Riva, R.; Schmeits, S.; Rieger, J.; Van Butsele, K.; Jérôme, C.; Jérôme, R. New Prospects for the Grafting of Functional Groups onto Aliphatic Polyesters. RingOpening Polymerization of $\alpha$ - or $\gamma$-Substituted $\varepsilon$-Caprolactone Followed by Chemical Derivatization of the Substituents. Macromol. Symp. 2006, 240, 157-165.

7. Habnouni, S. E.; Darcos, V.; Coudane, J. Synthesis and Ring Opening Polymerization of a New Functional Lactone, $\alpha$-Iodo- $\varepsilon$-caprolactone: A Novel Route to Functionalized Aliphatic Polyesters. Macromol. Rapid Commun. 2009, 30, 165-169.

8. Pounder, R. J.; Dove, A. P. Towards poly(ester) nanoparticles: recent advances in the synthesis of functional poly(ester)s by ring-opening polymerization. Polym. Chem. 2010, $1,260-271$.

9. Delplace, V.; Nicolas, J. Degradable vinyl polymers for biomedical applications. Nature Chem. 2015, 7, 771-84.

10. Tardy, A.; Nicolas, J.; Gigmes, D.; Lefay, C.; Guillaneuf, Y. Radical Ring-Opening Polymerization: Scope, Limitations, and Application to (Bio)Degradable Materials. Chem. Rev. 2017, 117, 1319-1406. 
11. Agarwal, S. Chemistry, chances and limitations of the radical ring-opening polymerization of cyclic ketene acetals for the synthesis of degradable polyesters. Polym. Chem. 2010, 1, 953-964.

12. Paulusse, J. M.; Amir, R. J.; Evans, R. A.; Hawker, C. J. Free Radical Polymers with Tunable and Selective Bio- and Chemical Degradability. J. Am. Chem. Soc. 2009, 131, 9805-9812.

13. Bailey, W. J.; Ni, Z.; Wu, S.-R. Synthesis of poly-€-caprolactone via a free radical mechanism. Free radical ring-opening polymerization of 2-methylene-1,3-dioxepane. $J$. Polym. Sci., Part A: Polym. Chem. 1982, 20, 3021-3030.

14. Bailey, W. J.; Wu, S.-R.; Ni, Z. Synthesis and free radical ring-opening polymerization of 2-methylene-4-phenyl-1,3-dioxolane. Makromol. Chem. 1982, 183, 1913-1920.

15. Bailey, W. J. Free Radical Ring-Opening Polymerization. Polym. J. 1985, 17, 85-95.

16. Bailey, W. J.; Ni, Z.; Wu, S. R. Free Radical Ring-Opening Polymerization of 4,7Dimethyl-2-methylene-1,3-dioxepane and 5,6-Benzo-2-methylene- 1,3-dioxepane. Macromolecules 1982, 15, 711-714.

17. Bailey, W. J.; Zhou, L.-L. A New Elimination with Phase-Transfer Catalysis for Cyclic Ketene Acetals. Tetrahedron Lett. 1991, 32, 1539-1540.

18. Chung, I. S.; Matyjaszewski, K. Synthesis of Degradable Poly(methyl methacrylate) via ATRP: Atom Transfer Radical Ring-Opening Copolymerization of 5-Methylene-2phenyl-1,3-dioxolan-4-one and Methyl Methacrylate. Macromolecules 2003, 36, 29952998.

19. Lutz, J.-F.; Andrieu, J.; Üzgün, S.; Rudolph, C.; Agarwal, S. Biocompatible, Thermoresponsive, and Biodegradable: Simple Preparation of "All-in-One" Biorelevant Polymers. Macromolecules 2007, 40, 8540-8543.

20. Agarwal, S.; Ren, L. Polycaprolactone-Based Novel Degradable Ionomers by Radical Ring-Opening Polymerization of 2-Methylene-1,3-dioxepane. Macromolecules 2009, 42, 1574-1579.

21. Kobben, S.; Ethirajan, A.; Junkers, T. Synthesis of degradable poly (methyl methacrylate) star polymers via RAFT copolymerization with cyclic ketene acetals. J. Polym. Sci., Part A: Polym. Chem. 2014, 52, 1633-1641.

22. Huang, J.; Gil, R.; Matyjaszewski, K. Synthesis and characterization of copolymers of 5,6-benzo-2-methylene-1,3-dioxepane and n-butyl acrylate. Polymer 2005, 46, 1169811706.

23. Hedir, G. G.; Bell, C. A.; Ieong, N. S.; Chapman, E.; Collins, I. R.; O’Reilly, R. K.; Dove, A. P. Functional degradable polymers by xanthate-mediated polymerization. Macromolecules 2014, 47, 2847-2852.

24. Hedir, G. G.; Bell, C. A.; O’Reilly, R. K.; Dove, A. P. Functional degradable polymers by radical ring-opening copolymerization of MDO and vinyl bromobutanoate: synthesis, degradability and post-polymerization modification. Biomacromolecules 2015, 16, 20492058.

25. Ganda, S.; Jiang, Y.; Thomas, D. S.; Eliezar, J.; Stenzel, M. H. Biodegradable glycopolymeric micelles obtained by RAFT-controlled radical ring-opening polymerization. Macromolecules 2016, 49, 4136-4146. 
26. Undin, J.; Finne-Wistrand, A.; Albertsson, A.-C. Adjustable Degradation Properties and Biocompatibility of Amorphous and Functional Poly(ester-acrylate)-Based Materials. Biomacromolecules 2014, 15, 2800-2807.

27. Undin, J.; Illanes, T.; Finne-Wistrand, A.; Albertsson, A.-C. Random introduction of degradable linkages into functional vinyl polymers by radical ring-opening polymerization, tailored for soft tissue engineering. Polym. Chem. 2012, 3, 1260-1266.

28. Jin, Q.; Maji, S.; Agarwal, S. Novel amphiphilic, biodegradable, biocompatible, crosslinkable copolymers: synthesis, characterization and drug delivery applications. Polym. Chem. 2012, 3, 2785-2793.

29. Hedir, G. G.; Arno, M. C.; Langlais, M.; Husband, J. T.; O'Reilly, R. K.; Dove, A. P. Poly(oligo(ethylene glycol) vinyl acetate)s: A Versatile Class of Thermoresponsive and Biocompatible Polymers. Angewandte Chemie International Edition 2017, 56, 91789182.

30. Tardy, A.; Honoré, J.-C.; Tran, J.; Siri, D.; Delplace, V.; Bataille, I.; Letourneur, D.; Perrier, J.; Nicoletti, C.; Maresca, M.; Lefay, C.; Gigmes, D.; Nicolas, J.; Guillaneuf, Y. Radical Copolymerization of Vinyl Ethers and Cyclic Ketene Acetals as a Versatile Platform to Design Functional Polyesters. Angew. Chem., Int. Ed. 2017, 56, 1651516520.

31. Tran, J.; Guégain, E.; Ibrahim, N.; Harrisson, S.; Nicolas, J. Efficient synthesis of 2methylene-4-phenyl-1,3-dioxolane, a cyclic ketene acetal for controlling the NMP of methyl methacrylate and conferring tunable degradability. Polym. Chem. 2016, 7, 44274435 .

32. Fessi, H.; Puisieux, F.; Devissaguet, J. P.; Ammoury, N.; Benita, S. Nanocapsule formation by interfacial polymer deposition following solvent displacement. Int. J. Pharm. 1989, 55, R1-R4.

33. Tobío, M.; Gref, R.; Sánchez, A.; Langer, R.; Alonso, M. J. Stealth PLA-PEG Nanoparticles as Protein Carriers for Nasal Administration. Pharm. Res. 1998, 15, 270275.

34. Quintanar-Guerrero, D.; Fessi, H.; Allémann, E.; Doelker, E. Influence of stabilizing agents and preparative variables on the formation of poly(d,1-lactic acid) nanoparticles by an emulsification-diffusion technique. Int. J. Pharm. 1996, 143, 133-141.

35. Mackiewicz, N.; Nicolas, J.; Handké, N.; Noiray, M.; Mougin, J.; Daveu, C.; Lakkireddy, H. R.; Bazile, D.; Couvreur, P. Precise Engineering of Multifunctional PEGylated Polyester Nanoparticles for Cancer Cell Targeting and Imaging. Chem. Mater. 2014, 26, 1834-1847.

36. Gref, R.; Lück, M.; Quellec, P.; Marchand, M.; Dellacherie, E.; Harnisch, S.; Blunk, T.; Müller, R. H. 'Stealth' corona-core nanoparticles surface modified by polyethylene glycol (PEG): influences of the corona (PEG chain length and surface density) and of the core composition on phagocytic uptake and plasma protein adsorption. Colloids Surf., B 2000, 18, 301-313.

37. Rostovtsev, V. V.; Green, L. G.; Fokin, V. V.; Sharpless, K. B. A Stepwise Huisgen Cycloaddition Process: Copper(I)-Catalyzed Regioselective "Ligation" of Azides and Terminal Alkynes. Angew. Chem., Int. Ed. 2002, 41, 2596-2599. 
38. Himo, F.; Lovell, T.; Hilgraf, R.; Rostovtsev, V. V.; Noodleman, L.; Sharpless, K. B.; Fokin, V. V. Copper(I)-Catalyzed Synthesis of Azoles. DFT Study Predicts Unprecedented Reactivity and Intermediates. J. Am. Chem. Soc. 2005, 127, 210-216.

39. Guo, X.; Shi, C.; Wang, J.; Di, S.; Zhou, S. pH-triggered intracellular release from actively targeting polymer micelles. Biomaterials 2013, 34, 4544-4554.

40. Rannard, S. P.; Davis, N. J. Controlled Synthesis of Asymmetric Dialkyl and Cyclic Carbonates Using the Highly Selective Reactions of Imidazole Carboxylic Esters. Org. Lett. 1999, 1, 933-936.

41. Kabanov, A. V.; Batrakova, E. V.; Alakhov, V. Y. Pluronic ${ }^{\circledR}$ block copolymers as novel polymer therapeutics for drug and gene delivery. J. Control. Rel. 2002, 82, 189-212.

42. Veronese, F. M.; Pasut, G. PEGylation, successful approach to drug delivery. Drug Discov. Today 2005, 10, 1451-1458.

43. Gref, R.; Domb, A.; Quellec, P.; Blunk, T.; Müller, R. H.; Verbavatz, J. M.; Langer, R. The controlled intravenous delivery of drugs using PEG-coated sterically stabilized nanospheres. Adv. Drug Delivery Rev. 1995, 16, 215-233.

44. Gref, R.; Minamitake, Y.; Peracchia, M.; Trubetskoy, V.; Torchilin, V.; Langer, R. Biodegradable long-circulating polymeric nanospheres. Science 1994, 263, 1600-1603.

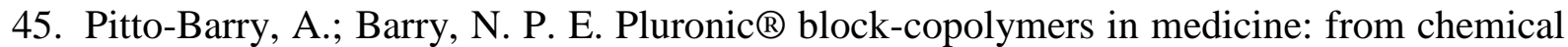
and biological versatility to rationalisation and clinical advances. Polym. Chem. 2014, 5, 3291-3297.

46. Owens, D. E.; Peppas, N. A. Opsonization, biodistribution, and pharmacokinetics of polymeric nanoparticles. Int. J. Pharm. 2006, 307, 93-102.

47. Gigmes, D.; Van Steenberge, P. H. M.; Siri, D.; D'hooge, D. R.; Guillaneuf, Y.; Lefay, C. Simulation of the Degradation of Cyclic Ketene Acetal and Vinyl-Based Copolymers Synthesized via a Radical Process: Influence of the Reactivity Ratios on the Degradability Properties. Macromol. Rapid Commun. 0, 1800193.

48. Guégain, E.; Michel, J.-P.; Boissenot, T.; Nicolas, J. Tunable Degradation of Copolymers Prepared by Nitroxide-Mediated Radical Ring-Opening Polymerization and Point-byPoint Comparison with Traditional Polyesters. Macromolecules 2018, 51, 724-736.

49. Tsuji, H.; Ikarashi, K. In Vitro Hydrolysis of Poly(l-lactide) Crystalline Residues as Extended-Chain Crystallites: II. Effects of Hydrolysis Temperature. Biomacromolecules 2004, 5, 1021-1028.

50. Taylor, M. S.; Daniels, A. U.; Andriano, K. P.; Heller, J. Six bioabsorbable polymers: In vitro acute toxicity of accumulated degradation products. J. Appl. Biomater. 1994, 5, 151157.

51. Ignatius, A. A.; Claes, L. E. In vitro biocompatibility of bioresorbable polymers: poly(L, DL-lactide) and poly(L-lactide-co-glycolide). Biomaterials 1996, 17, 831-839.

52. Vert, M.; Li, S. M.; Spenlehauer, G.; Guerin, P. Bioresorbability and biocompatibility of aliphatic polyesters. J. Mater. Sci.: Mater. Med. 1992, 3, 432-446.

53. Tokiwa, Y.; Calabia, B. P. Biodegradability and Biodegradation of Polyesters. J. Polym. Environ. 2007, 15, 259-267. 
54. Becker, M. L.; Remsen, E. E.; Pan, D.; Wooley, K. L. Peptide-derivatized shellcrosslinked nanoparticles. 1. synthesis and characterization. Bioconjugate Chem. 2004, 15, 699-709.

55. He, F.; Li, S.; Vert, M.; Zhuo, R. Enzyme-catalyzed polymerization and degradation of copolymers prepared from $\epsilon$-caprolactone and poly(ethylene glycol). Polymer 2003, 44, 5145-5151.

56. VanKooten, T. G.; Klein, C. L.; Kohler, H.; Kirkpatrick, C. J.; Williams, D. F.; Eloy, R. From cytotoxicity to biocompatibility testing in vitro: cell adhesion molecule expression defines a new set of parameters. J. Mater. Sci.: Mater. Med. 1997, 8, 835-841.

57. Kirkpatrick, C. J.; Otto, M.; Kooten, T. V.; Krump, V.; Kriegsmann, J.; Bittinger, F. Endothelial cell cultures as a tool in biomaterial research. J. Mater. Sci.: Mater. Med. 1999, 10, 589-594.

58. Peracchia, M. T.; Vauthier, C.; Desmaële, D.; Gulik, A.; Dedieu, J.-C.; Demoy, M.; d'Angelo, J.; Couvreur, P. Pegylated Nanoparticles from a Novel Methoxypolyethylene Glycol Cyanoacrylate-Hexadecyl Cyanoacrylate Amphiphilic Copolymer. Pharm. Res. 1998, $15,550-556$.

59. Sanchez De Juan, B.; Von Briesen, H.; Gelperina, S. E.; Kreuter, J. Cytotoxicity of doxorubicin bound to poly(butyl cyanoacrylate) nanoparticles in rat glioma cell lines using different assays. J. Drug Targeting 2006, 14, 614-622.

60. Brambilla, D.; Nicolas, J.; Le Droumaguet, B.; Andrieux, K.; Marsaud, V.; Couraud, P.O.; Couvreur, P. Design of fluorescently tagged poly(alkyl cyanoacrylate) nanoparticles for human brain endothelial cell imaging. Chem. Commun. 2010, 46, 2602-2604.

61. Barraud, L.; Merle, P.; Soma, E.; Lefrançois, L.; Guerret, S.; Chevallier, M.; Dubernet, C.; Couvreur, P.; Trépo, C.; Vitvitski, L. Increase of doxorubicin sensitivity by doxorubicin-loading into nanoparticles for hepatocellular carcinoma cells in vitro and in vivo. J. Hepatol. 2005, 42, 736-743.

62. Merle, P.; Ahmed, S. S.; Habersetzer, F.; Abergel, A.; Taieb, J.; Bonyhay, L.; Costantini, D.; Dufour-Lamartinie, J.; Trepo, C. Phase 1 study of intra-arterial hepatic (IAH) delivery of doxorubicin-transdrug (DT) for patients with advanced hepatocellular carcinoma (HCC). J. Clin. Oncol. 2006, 24, 14094-14094.

63. Zhou, Q.; Sun, X.; Zeng, L.; Liu, J.; Zhang, Z. A randomized multicenter phase II clinical trial of mitoxantrone-loaded nanoparticles in the treatment of 108 patients with unresected hepatocellular carcinoma. Nanomedicine: NBM 2009, 5, 419-423.

64. Doxorubicin Transdrug®: significant increased survival rate in patients with advanced hepatocellular carcinoma treated in a phase II clinical trial. Bioalliance web document 2009; 8 Dec

65. Neal, J. C.; Stolnik, S.; Schacht, E.; Kenawy, E. R.; Garnett, M. C.; Davis, S. S.; Illum, L. In Vitro Displacement by Rat Serum of Adsorbed Radiolabeled Poloxamer and Poloxamine Copolymers from Model and Biodegradable Nanospheres. J. Pharm. Sci. 1998, 87, 1242-1248. 


\section{For Table of Contents Use Only}

Degradable Copolymer Nanoparticles from Radical Ring-Opening Copolymerization between Cyclic Ketene Acetals and Vinyl Ethers

Johanna Tran, Théo Pesenti, Jonathan Cressonnier, Catherine Lefay, Didier Gigmes, Yohann Guillaneuf, Julien Nicolas*

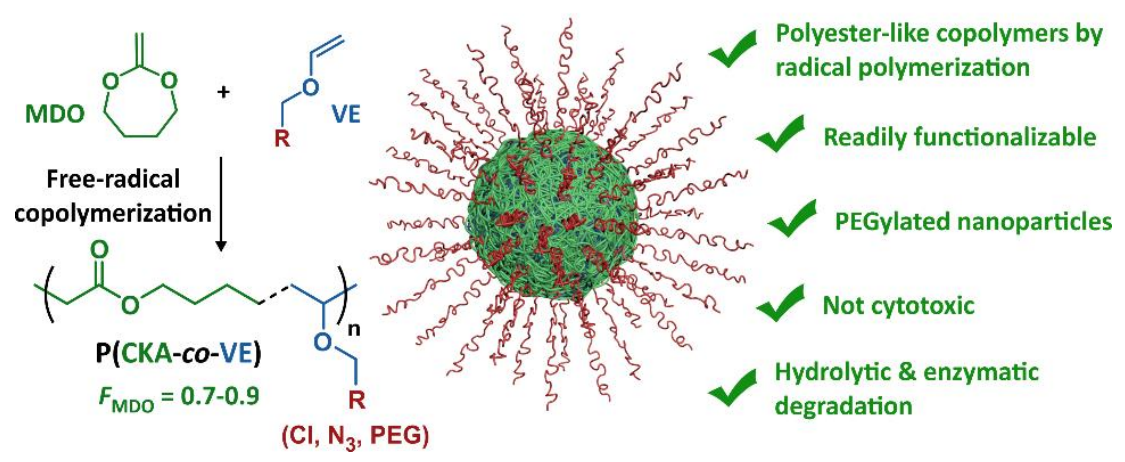

